\title{
Southern Hemisphere Westerly Wind Changes during the Last Glacial Maximum: Model-Data Comparison
}

\author{
Louise C. Sime ${ }^{a}$, Karen E. Kohfeld ${ }^{b}$, Corinne Le Quéréc ${ }^{c}$ Eric W. Wolff ${ }^{a}$, \\ Agatha M. de Boer ${ }^{d}$, Robert M. Graham ${ }^{d}$, Laurent Bopp ${ }^{e}$ \\ ${ }^{a}$ British Antarctic Survey, Cambridge, CB3 OET, U.K. \\ ${ }^{b}$ Simon Fraser University, 8888 University Drive, Burnaby, V5A 1S6, Canada \\ ${ }^{c}$ School of Environmental Sciences, University of East Anglia, Norwich, NR4 7TJ, U.K \\ ${ }^{d}$ Department of Geological Sciences, Stockholm University, 10691 Stockholm, Sweden \\ ${ }^{e}$ Centre National de la Recherche Scientifique, CEA, Saclay, 91191, France
}

\begin{abstract}
The Southern Hemisphere (SH) westerly winds are thought to be critical 2 to global ocean circulation, productivity, and carbon storage. For example, 3 an equatorward shift in the winds, though its affect on the Southern Ocean circulation, has been suggested as the leading cause for the reduction in at5 mospheric $\mathrm{CO}_{2}$ during the last glacial period. Despite the importance of 6 the winds, it is currently not clear, from observations or model results, how 7 they behave during the last glacial. Here, an atmospheric modelling study 8 is performed to help determine likely changes in the SH westerly winds dur9 ing the Last Glacial Maximum (LGM). Using LGM boundary conditions, o the maximum in $\mathrm{SH}$ westerlies is strengthened by $\sim+1 \mathrm{~ms}^{-1}$ and moved 1 southward by $\sim 2^{\circ}$ at the $850 \mathrm{hPa}$ pressure level. Boundary layer stabilisation 2 effects over equatorward extended LGM sea-ice can lead to a small appar3 ent equatorward shift in the wind band at the surface. Further sensitivity 14 analysis with individual boundary condition changes indicate that changes ${ }_{5}$ in sea surface temperatures are the strongest factor behind the wind change. 6 The HadAM3 atmospheric simulations, along with published PMIP2 coupled 7 climate model simulations, are then assessed against the newly synthesised 1 database of moisture observations for the LGM. Although the moisture data 9 is the most commonly cited evidence in support of a large equatorward shift 20 in the SH winds during the LGM, none of the models that produce realistic 21 LGM precipitation changes show such a large equatorward shift. In fact, 22 the model which best simulates the moisture proxy data is the HadAM3 2 LGM simulation which shows a small poleward wind shift. While we cannot
\end{abstract}


prove here that a large equatorward shift would not be able to reproduce the moisture data as well, we show that the moisture proxies do not provide an observational evidence base for it.

Keywords: glacial-interglacial cycles, westerly winds, Southern Ocean, LGM, atmospheric modelling, PMIP2, data-model comparison

\section{Introduction}

The location and the strength of Southern Hemisphere (SH) westerly winds play a critical role in global climate, with glacial-interglacial change in $\mathrm{CO}_{2}$ strongly linked to ocean-atmosphere circulation feedbacks mediated through the SH wind field (Sigman and Boyle, 2000; Toggweiler et al., 2006; Levermann et al., 2007; Toggweiler and Russell, 2008; Toggweiler, 2009; Denton et al., 2010; De Boer et al., 2010). For example, oceanic carbon sequestration depends strongly on Southern Ocean circulation, which is influenced by this wind field (Toggweiler, 1999; Wunsch, 2003; Le Quéré et al., 2007; Toggweiler and Russell, 2008). If glacial period equatorward positioned westerlies occurred, it is thought that they would curtail deep water ventilation and lead to a more stratified ocean (Toggweiler and Samuels, 1995, 1998). Isolated deep water traps carbon and leads to a reduction in atmospheric $\mathrm{CO}_{2}$ (Toggweiler, 1999; Watson and Naveira Garabato, 2006; Skinner et al., 2010; Sigman et al., 2010).

In addition to this primary ocean- $\mathrm{CO}_{2}$ modulation mechanism, other potential oceanic impacts of wind changes have been identified. The impact of SH winds on North Atlantic Deep Water (NADW) formation through dynamical processes has been established (Toggweiler and Samuels, 1993, 1995; Rahmstorf and England, 1997; Nof and De Boer, 2004; De Boer and Nof, 2005; De Boer et al., 2008). Another hypothesis that has recently gained prominence is the suggestion that SH westerly winds affect NADW formation though its modulation of Agulhas Leakage (Sijp and England, 2009; Beal et al., 2011; Caley et al., 2012), the idea being that an equatorward shift in the SH winds forces a similar shift in the Subtropical Front, in turn reducing the amount of high salinity Indian Ocean water that enters the Atlantic Ocean. The decrease in Atlantic salt input then translates into a weaker Atlantic meridional overturning.

Outwith the ocean, changes in the SH westerlies may also modify other parts of the climate system that are critical to the ocean-atmospheric $\mathrm{CO}_{2}$ 
balance. For example, iron rich dust borne by $\mathrm{SH}$ winds affects Southern Ocean productivity, thereby influencing the ocean-atmosphere carbon budget (Kohfeld et al., 2005).

Given this critical importance of SH westerly winds for the ocean circulation and climate, it is thus important that we both understand what controls their changes and how we can read wind changes from paleo-enviromental evidence.

Kohfeld et al. (submitted) discussed how the location and strength of the westerly winds during the glacial period have been inferred using reconstructed paleo-changes in moisture conditions and sometimes oceanic front shifts (Bard and Rickaby, 2009; Kohfeld et al., submitted). Inferred changes in precipitation reconstructed from vegetation regimes, lakes, glaciers, and other precipitation sensitive paleo-environments have been interpreted as equatorward shifts in the winds as large as $7-10^{\circ}$ relative to their interglacial position (Heusser, 1989; Lamy et al., 1999; Moreno et al., 1999; Toggweiler, 1999; Toggweiler et al., 2006; Toggweiler and Russell, 2008; Toggweiler, 2009).

We note here that this interpretation has arisen from the relationship between present-day SH westerlies and precipitation (Fig. 1ac). Thus, in places such as South America, an equatorward shift in westerly winds during the last glacial period has been inferred from data that demonstrate enhanced precipitation to the north of the modern-day position of the SH westerlies, and colder drier conditions in more southerly locations (Heusser, 1989; Lamy et al., 1999; Moreno et al., 1999). This proposed shift has often been associated with a proposed glacial weakening of the Hadley cell (Williams and Bryan, 2006; Toggweiler and Russell, 2008; Toggweiler, 2009; Denton et al., 2010). See Kohfeld et al. (submitted) for additional details and other possible interpretations of this data.

Model studies do not agree on the position and strength of the westerly winds during the Last Glacial Maximum (LGM - 19-23 ky) conditions. Studies using coupled Atmosphere-Ocean General Circulation Models (AOGCM) have suggested that the westerlies move equatorward (Williams and Bryan, 2006) and weaken (Kim et al., 2002, 2003); move poleward and strengthen (Shin et al., 2003); move poleward (Kitoh et al., 2001); or increase in strength with no latitudinal shift (Otto-Bliesner et al., 2006). Analysis of more recent AOGCM Paleoclimate Modelling Intercomparison Project 2 (PMIP2) wind results still shows similar variation between different models (Menviel et al., 2008; Rojas et al., 2009). Likewise, studies using atmosphere-only General Circulation Models (AGCMs) have shown both equatorward (Drost et al., 
2007) and poleward shifts (Wyrwoll et al., 2000).

This apparent disconnect between modelling results and paleo-observations represents a serious gap in our knowledge about the nature of changes in westerly winds, and our ability to understand the impacts of these changes. This paper represents the second of two research contributions to examine how westerly winds behaved during the LGM. In our first paper (Kohfeld et al., submitted), we synthesize and summarise interpretations of paleoenviromental observations relating to the $\mathrm{SH}$ westerlies during the LGM. We conclude that resolving the position and strength of the westerly winds based on this data alone remains difficult because of several possible interpretations. Kohfeld et al. (submitted) shows that that although atmospheric evidence has been frequently used to support the hypothesised large equatorward shift or strengthening, the assumptions used have not been tested previously.

Here, our goal is to make progress through modelling, and by an atmospheric data-model intercomparison. To this purpose we perform a set of atmospheric modelling experiments to simulate the glacial winds using LGM boundary conditions. We further test the sensitivity of the winds to each individual LGM boundary condition change. In section 2 we lay out the design of the atmospheric modelling experiments, note the PMIP2 AOGCM coupled simulations to which we compare our results, and explain how we quantify the comparison of model output with observations. In section 3, we explore how SH westerly winds change in response to individual LGM boundary condition changes. In section 4, we explore the $\mathrm{SH}$ moisture changes, comparing HadAM3 AGCM and PMIP2 AOGCM moisture changes with the main Kohfeld et al. (submitted) moisture observation synthesis. Implications of the results are discussed within the context of observed dust and oceanic front changes in section 5 .

\section{Experiment design}

\subsection{AGCM (HadAM3) model description}

To test the sensitivity of $\mathrm{SH}$ winds and moisture to changes in glacialinterglacial atmospheric boundary conditions, experiments are set-up using an atmospheric-only model HadAM3 on a regular latitude longitude grid with a horizontal resolution of $2.5^{\circ} \times 3.75^{\circ}$, and 20 hybrid coordinate levels in the vertical (Pope et al., 2000). HadAM3 features a good representation of present day model climatology (Pope et al., 2000). Where the model is run in its coupled state (HadCM3), it features a reasonable representation (Fig 1b) 
of the mean annual SH westerlies (Russell et al., 2006) and produces realistic simulations of coupled wind dependent low frequency variability (Gordon et al., 2000; Collins et al., 2001; Sime et al., 2006). This suggests that the atmospheric response to sea surface temperature and sea-ice change is reliable. A pre-industrial control simulation is performed along with 9 LGM sensitivity experiments.

\subsection{Simulation boundary conditions}

The prescribed boundary conditions for each model integration includes values for sea surface temperature, sea-ice, land-ice, solar insolation, and atmospheric gas concentrations.

The sea surface temperature and sea-ice data for our pre-industrial (PI) control simulation are based on a twenty year monthly average of HadiSST data (Rayner et al., 2003). Ice-sheet volume (and therefore also the land-sea masking) and insolation conditions are taken from the present-day, but atmospheric gas composition is set to pre-industrial values $\left(\mathrm{CO}_{2}\right.$ is $280 \mathrm{ppmv}$; $\mathrm{CH}_{4}$ is $0.76 \mathrm{ppmv}$; and $\mathrm{N}_{2} \mathrm{O}$ is $0.27 \mathrm{ppmv}$ ). $\mathrm{SH}$ westerly winds in this preindustrial simulation (Fig. 1a) are close to the early period European Centre for Medium-Range Weather Forecasts (ECMWF) zonal winds (Fig. 1b); early period data are used to validate the model simulation to minimise the effect of warming or ozone changes on the comparison (Shindell and Schmidt, 2004). Similarly, the pre-industrial precipitation, is also in reasonable agreement with ECMWF precipitation. The comparison between ECMWF and the control simulation suggests that the $\mathrm{SH}$ westerlies and the precipitation regime in the HadAM3 pre-industrial experiment are reasonable in comparison with coupled model results (Russell et al., 2006).

For the LGM, the most recent compilation of sea surface temperature data is from the MARGO project MARGO Project Members (2009). We treat it here as the best observational estimate available of glacial sea surface conditions. However, at present, the MARGO compilation has not been interpolated to produce a globally gridded dataset. A global dataset is required to drive a global atmospheric general circulation model. The most recent gridded version of the GLAMAP LGM (19-22 ky) sea surface conditions (Paul and Schäfer-Neth, 2003a,b) is therefore used to drive the HadAM3 experiments (Fig. 2). Fig. 3a shows the difference between the gridded GLAMAP sea surface temperatures and sea-ice values and the MARGO data. The GLAMAP LGM sea surface temperatures are mainly within 1-2 $\mathrm{K}$ of the 
nearest MARGO values. However, some larger regional discrepancies occur, particularly around New Zealand, GLAMAP values here are generally 2-4 K too warm. The GLAMAP dataset is also used for our LGM sea-ice conditions.

LGM sea surface temperature data is rather sparse poleward of $40^{\circ} \mathrm{S}$, leading to difficulty in establishing accurate meridional temperature gradients in this region (MARGO Project Members, 2009). However, paleo-observations of sea-ice extent allows estimation of the sea surface temperatures near the geographical LGM sea-ice limit (at about $55^{\circ} \mathrm{S}$ ), at roughly minus $2^{\circ} \mathrm{C}$ (Gersonde et al., 2005). Thus we have reasonable confidence that there was a steeper LGM extra-tropical temperature gradient (Paul and Schäfer-Neth, 2003b). Compared with the polar regions, there are more glacial sea surface temperature observations from the tropical regions (Paul and Schäfer-Neth, 2003b; MARGO Project Members, 2009). These extra observations improve confidence in the tropical boundary conditions.

Orbitally dependent insolation for the LGM (Laskar et al., 2004) and the atmospheric greenhouse gas composition $\left(\mathrm{CO}_{2}\right.$ is $185 \mathrm{ppmv} ; \mathrm{CH}_{4}$ is 0.35 ppmv; and $\mathrm{N}_{2} \mathrm{O}$ is $0.20 \mathrm{ppmv}$ ) is taken from the specified PMIP2 boundary conditions (Braconnot et al., 2007)) and are known relatively well. Although there is uncertainty about detailed aspects of the East Antarctic glacial ice-sheet morphology, we have used the broad-scale glacial-interglacial ICE-5G(VM2) model mass changes in which there is reasonable confidence (Peltier, 2004).

\subsection{AGCM (HadAM3) sensitivity simulations}

In addition to the PI control simulation,nine atmospheric-only GCM simulations are used to assess the LGM SH wind and moisture changes. The most realistic LGM experiment, named LGM, applies all the known boundary conditions for that period as described in the previous section. The individual sensitivity experiments are designed to simulate the effect of the various observed LGM changes in sea surface temperatures, sea-ice, ice-sheets, incoming solar radiation, and atmospheric gas composition. The experiments are generated by varying one boundary condition at a time from the PI to the LGM conditions (Table 1). The atmospheric simulations are run for 30 years, which is long enough to allow the atmosphere to reach an equilibrium state with the specified boundary conditions (for atmospheric-only simulations, an equilibrium state is reached after approximately two to four 
weeks). Results are presented as differences between pre-industrial and the LGM-based simulations.

The details of the sensitivity experiments are as follows. The SST experiment is identical to PI except using LGM sea surface temperature values. The SEAICE experiment is identical to PI, except that LGM sea-ice conditions are applied, i.e. this experiment uses LGM sea-ice-conditions, but pre-industrial sea surface temperatures. This means that in the experiment SEAICE sea-ice is prescribed in some areas where the surface temperature is above $-1.8^{\circ} \mathrm{C}$. The individual SST and SEAICE experiments are not intended to represent realistic simulations of past conditions, but are useful as they allow us to investigate separately the boundary condition effect of sea surface temperature and sea-ice changes. SST SEAICE is more realistic since it combines the sea surface temperature and sea-ice conditions from the SST and SEAICE experiments. The TRO and EXT experiments are variations of the SST SEAICE experiments. SST TRO is based on PI but has the LGM GLAMAP reconstruction imposed equatorward of $20^{\circ}$ with a linear reduction in the anomaly imposed between $20^{\circ}$ and $30^{\circ}$ : poleward of $30^{\circ} \mathrm{SST}$ TRO is identical to PI. Similarly, SST EXT has the GLAMAP sea surface reconstruction imposed between $90^{\circ}$ and $30^{\circ}$, with a linear reduction to zero between $30^{\circ}$ and $20^{\circ}$, and PI conditions equatorward of $20^{\circ}$. LAND ICE ice-sheet volume, ice-sheet topography, and land-sea masking is adjusted to LGM conditions. ORBIT varies from the PI experiment in orbital parameters. GAS uses LGM atmospheric gas composition values. The HadAM3 LGM experiment combines all the different LGM changes.

To help examine the impact of uncertainties in the sea surface temperature observations, twelve additional sensitivity simulations were also performed. See Appendix A for these additional experiments.

\subsection{Description of AOGCM (PMIP2) simulations}

To assess the robustness of the results from the AGCM HadAM3 experiments, the published AOGCM PMIP2 simulations are also analysed where surface and $850 \mathrm{HPa}$ wind and precipitation fields are available. The AOGCM pre-industrial simulations are similar in specification to the full LGM AGCM simulation, except that they are run with a full dynamic ocean and sea-ice model, rather than with specified sea surface conditions (Table 1). The simulations are run for long enough to allow the atmosphere and oceans reach quasi-equilibrium state to the specified boundary conditions and for 
trends to become small (Rojas et al., 2009). In these ocean-atmosphere simulations, the pre-industrial SH westerlies band is less well simulated compared to our atmospheric-only simulation, with a general bias towards westerlies that are too intense and located too far north (Fig. 1b). These pre-industrial simulation errors hinder comparison with the glacial simulation winds. This difficulty can cloud the picture of interglacial to glacial wind changes obtained from AOGCM simulations (Rojas et al. 2009). However, their atmosphere, ocean, and sea-ice components are dynamically consistent with each other (Rojas et al., 2009) and analysis of these coupled simulations sheds light on the sensitivity of our results to model choice.

Analysing coupled AOGCM LGM multi-model simulations, alongside core AGCM simulations, ensures that a wide possible range of LGM model results are considered. The comparison between MARGO sea surface temperature data and the two PMIP2 simulations, for which we have the comparative sea surface temperature output, suggests that as we might expect the LGM sea surface conditions are slightly better represented by the observationally based GLAMAP AGCM boundary condition data, compared to the AOGCM simulations (Fig. 3). Some problems in the accuracy of simulated LGM sea surface conditions from coupled atmospheric-ocean models may be due to difficulties in accurately parameterising glacial ocean mixing terms (Wunsch, 2003; Watson and Naveira Garabato, 2006), and also partly a problem of model resolution. Both of these problems affect the simulation of the narrow Southern Ocean frontal jets which dominate the Southern Ocean surface temperature patterns. Further improvements in ocean model parameterisation, and also in model resolution, may in future help to resolve these glacial ocean simulation problems. These type of ocean modelling problems also afflict coupled PMIP2 pre-industrial simulations (Russell et al., 2006), thus errors in the pre-industrial ocean surface temperature simulation may be the cause of errors in the simulated pre-industrial SH westerly winds (Fig. $1 b)$.

\subsection{Data-model comparison metrics}

The Kohfeld et al. (submitted) paleo-observational study compiles evidence of widespread glacial-interglacial moisture changes in the SH. Simulation results are evaluated against 105 observations from 97 locations in this new synthesized moisture dataset, by visual inspection and using two quantitative approaches. The first quantitative approach compares simulated and observed changes at the 'exact' observation location, whilst the second checks 
for a 'local' match. The local-match approach helps allow for model-inability to represent small scale topographic features that are not represented in GCMs but may affect observations. Both model evaluation techniques allow the use of simple percentage statistics (Tables 1-3). This independent evaluation of the goodness of model simulations helps in allowing investigation of both glacial-interglacial SH circulation and moisture changes.

The assessment of the exact-type and local-type agreement between modelled and observed moisture matches is made by classing simulated precipitation changes as positive or negative, if they are larger than $\pm 5 \%$. This $5 \%$ threshold allows for a total $10 \%$ to be attributable to uncertainty in the interpretation of proxies, or simulation of the changes. A simulated change of less than $5 \%$ is classified as no change. This threshold is narrow compared to discussion on pollen-proxy sensitivity (Bartlein et al., 2011), however recent evaluations of model simulations against paleo-data have shown that models tend to underestimate the magnitude of precipitation changes, particularly regional changes (Braconnot et al., 2012). Our result here support the Braconnot et al. (2012) finding: the 5\% threshold gives a better match with paleo-data compared with using a wider $\pm 10 \%$ threshold (not shown).

In the exact-type approach, simulation change values are linearly interpolated to the exact observation site before the threshold is applied. The number of sites which match the observed changes can then be presented as simple percentage statistic, i.e. if 20 of 100 observations match, then the simulation scores $20 \%$ (Table 1). For a local-type approach, simulation changes are calculated as above (using the same threshold), but rather than interpolate directly to the observation site, the simulation results (on the original model grid) are searched within a given radius for a locally correct match (Table 1, last column). This local approach helps allow for model inability to represent localised effects of gradients on moisture: small-scale features affect observations but relatively coarse resolution models cannot simulate them. Even given the local-type method, it is unlikely that any relatively coarse resolution model study will achieve a perfect observation match.

The local-type percentage agreements are checked using a variety of spatial search radiuses. The main local-type match results given in Table 1 use a radius of $400 \mathrm{~km}$. This radius is used because it matches the approximate resolution of the model grid at the equator $\left(3.75^{\circ}\right.$ distance in longitude at $0^{\circ}$ latitude is $\left.417 \mathrm{~km}\right)$. However, as one moves towards the poles this distances decreases (e.g. it is $341 \mathrm{~km}$ at $35^{\circ} \mathrm{S}, 295 \mathrm{~km}$ at $45^{\circ} \mathrm{S}, 268 \mathrm{~km}$ at $50^{\circ} \mathrm{S}$, and so on). Largely because of this variation, it is not possible to choose 
a search radius where the 'local' and 'exact' model-observation agreement results are in perfect agreement. However, in general, reducing the radius towards about $250 \mathrm{~km}$ brings these results into rough agreement, since that means that usually about one model grid point is within the local search radius. We also present metrics in Table 2 and 3 using these alternative search radii. It can be argued that data-model metrics for the extra-tropical region, from $35^{\circ} \mathrm{S}$ to $90^{\circ} \mathrm{S}$ are the more relevant for understanding Southern Ocean westerly wind changes. We therefore also provide results for separate tropical $\left(0-35^{\circ} \mathrm{S}\right)$ and extra-tropical $\left(35-90^{\circ} \mathrm{S}\right)$ sub-domains in Tables 2 and 3 , and compare these results to those for the whole $\mathrm{SH}$ domain.

Due to the three-value nature of our results (wetter, drier, or no change) we cannot apply common statistical tests to the datasets. However, by randomising the relationship between the given observations against simulation results, we can calculate null agreement values for the simulations. Assuming the simulation of equal areas or wetter, drier, and no change in precipitation, the exact-type null value is $33 \%$, and the local-type null value is $57 \%$ for a $400 \mathrm{~km}$ radius, and $44 \%$ for $250 \mathrm{~km}$. Thus percentage values higher than these numbers indicate skill in the model simulation. Note whilst local-type null values vary slightly between simulations (due to the variable geographical pattern of changes), using the ECHAM5, MIROC3.2.2, and HadCM3 AOGCM LGM simulation, null results are within two percentage points of each other.

Moisture observations tend to reflect moisture flux (i.e. P-E). However, for HadAM3 simulations, the precipitation and moisture flux observationmodel local-type match comparisons are quite similar: within $10 \%$ of each other for simulations that do not involve ICE-5G; and with a maximum difference of $12 \%$ for simulations using ICE-5G. Since we do not have PMIP2 moisture flux fields available, observations are tested against simulation precipitation changes for both HadAM3 and coupled PMIP2 simulations (Table 1 , right columns).

\section{Simulated changes in LGM winds}

In our atmospheric LGM simulation full glacial boundary conditions are imposed and the results compared to the pre-industrial control. For this simulation, the $850 \mathrm{hPa}$ westerlies show a small increase poleward of $50^{\circ} \mathrm{S}$ $\left(+1.5 \mathrm{~ms}^{-1}\right.$ at $\left.60^{\circ} \mathrm{S}\right)$ and a small decrease northward of $50^{\circ} \mathrm{S}\left(-1 \mathrm{~ms}^{-1}\right.$ at $40^{\circ} \mathrm{S}$ ) leading to a maximum that is shifted poleward by about $2^{\circ}$ (Fig. 4). 
At $2^{\circ}$ the latitudinal shift of the $850 \mathrm{hPa}$ wind band obtained here is rather small and in the opposite direction from what has often been suggested (Toggweiler et al., 2006; Toggweiler and Russell, 2008; Toggweiler, 2009). In the core region of the westerlies, at about $52^{\circ} \mathrm{S}$, the maximum increases by approximately $+1 \mathrm{~ms}^{-1}$. We concentrate here on wind changes at $850 \mathrm{hPa}$ level, which are similar to those at the surface but do not include boundary layer effects due to sea-ice cover. Surface wind effects and moisture changes are considered in the later sections. Our sensitivity experiments (Table 1) allow the effect of various LGM boundary conditions to be compared to their individual impact on the atmospheric circulation (Fig. 5). The experiments are used to examine LGM changes in the westerlies due to: [1] extra-tropical and tropical sea surface conditions; and [2] orbitally dependent insolation, atmospheric gases, and the morphology of the Antarctic ice-sheet.

\subsection{The role of sea surface changes}

In the SST EXT simulation where tropical sea surface temperatures are held at pre-industrial levels and glacial sea surface temperatures are imposed poleward of $20^{\circ}$, a small $\sim 1^{\circ}$ poleward shift in the location of the winds maximum occurs. Pronounced cooling near the edge of the LGM Southern Ocean sea-ice (Fig. 5ab) and extended sea-ice coverage (Fig. 5c) drives a small intensification of the westerlies. The wind intensification is largest between $56-58^{\circ} \mathrm{S}$; approximately $5^{\circ}$ poleward of the pre-industrial maximum in the winds location (Fig. 6a). This pattern of change drives the small poleward shift in the location of the winds maximum. Observational evidence for extended Antarctic sea-ice (Gersonde et al., 2005), supports an increase in the glacial meridional temperature gradient around $55^{\circ} \mathrm{S}$. This steeper Southern Ocean surface meridional temperature gradient (Paul and Schäfer-Neth, 2003b; Gersonde et al., 2005), is associated with increased available potential energy (Wyrwoll et al., 2000; Wunsch, 2003), and increased potential atmospheric baroclinicity. Similar intensifications in the westerlies, due to southern cooling, are visible in the poleward intensifications of westerlies in some previous studies (Wyrwoll et al., 2000; Yin and Battisti, 2001; Kitoh et al., 2001).

In the SST TRO tropical simulations, sea surface temperatures equatorward of $20^{\circ}$ are set to glacial values, while Southern Ocean sea surface temperatures are set at pre-industrial values. In contrast to local temperature gradient effects discussed above, the tropical sea surface temperature changes affect atmospheric temperature gradients in regions distant from 
the band of SH westerlies. Reduced tropical sea surface temperatures cause pressure changes through modifications of the Rossby wave pattern (LachlanCope et al., 2007), particularly in the SH wavenumber-3 pattern (Marshall and Connolley, 2006). This leads to geographical variability in wind changes around the Southern Ocean (Yin and Battisti, 2001). The Indian Ocean sector experiences the largest changes, but every ocean basin sector sees an intensification of the glacial westerlies south of $50^{\circ} \mathrm{S}$ and a reduction to the north (Fig. 5de). This leads to a small $\sim 1^{\circ}$ poleward shift in the location of the winds maximum (Fig. 6a).

The detail of the glacial tropical sea surface temperatures is still a matter of ongoing research (MARGO Project Members, 2009), however analysis of additional sensitivity experiments (Appendix A) confirms that this small poleward shift in the $\mathrm{SH}$ westerlies appears to be a robust response to tropical cooling. Note a much larger uniform $-4 \mathrm{~K}$ tropical cooling causes a very similar, but intensified, pattern of wind changes (not shown).

\subsection{The roles of orbit, greenhouse gases, and ice volume}

In the orbital forcing and greenhouse gas simulations, these boundary conditions are changed to glacial values, whilst all other conditions are kept pre-industrial. The direct forcing of glacial-interglacial changes in orbital parameters and atmospheric gas composition on atmospheric circulation is small. Our results confirm that orbital changes do not lead to substantial changes between the pre-industrial and the LGM westerlies, whilst greenhouse gas changes lead to small reductions in the strength of the average westerlies (of $0.25-0.5 \mathrm{~ms}^{-1}$ ). These glacial boundary conditions only cause larger changes in the westerlies in ocean-atmosphere coupled GCMs where sea surface temperature and sea-ice feedbacks may amplify initial forcings (Rojas et al., 2009).

In the glacial ice volume simulation, glacial ice-sheets are imposed (Peltier, 2004), whilst other boundary conditions are kept pre-industrial. The changes, in continents other than Antarctica, have little effect on hemispheric scale wind patterns. However, the intensity of the westerlies south of $40^{\circ} \mathrm{S}$ decreases according to the prescribed size of the Antarctic ice-sheet (Fig. $5 f$ and $6 a b$, yellow line). Katabatic winds drain out from the Antarctic continental ice-sheet, causing northerly and weak easterly surface flows around the edge of the Antarctica (Fig. 1a, vectors). The higher ICE-5G (Peltier, 2004) LGM Antarctic ice-sheet results in steeper ice-sheet margin slopes, with resultant increases in the strength of the katabatic winds (Heinemann, 
2003). These more intense katabatic winds reduce the southward penetration of cyclones (Parish et al., 1994), which reduces the average intensity of the westerlies (Fig. 5f).

The Antarctic glacial ice volume increase (Peltier, 2004), together with the extra-tropical surface temperature effects, reduce the simulated East Antarctic Plateau LGM precipitation by approximately $70 \%$ (Fig. 7). This reduction is larger than the observed decrease of about 50\% (Parrenin et al., 2007), and supports independent gas pressure evidence that the East Antarctic ICE-5G ice-sheet elevation is probably too high (Masson-Delmotte et al., 2006). In this case, our simulations using the ICE-5G ice reconstruction may produce poleward westerly winds that are too weak; our Fig 6ab results suggest somewhere from $0.2-0.5 \mathrm{~ms}^{-1}$ too weak.

\subsection{The impact of wind prognostic choice}

One factor which has affected comparison of previous glacial-interglacial modelling studies is the choice of wind prognostic. Studies of SH circulation change have used: surface winds (Kim et al., 2003); above-surface winds; or surface shear stress (Otto-Bliesner et al., 2006). Where sea-ice replaces pre-industrial open water, each of these prognostics shows a different response. The intensity of surface winds is sensitive to the sea-ice extent because expanded sea-ice cover leads to weak turbulent fluxes, strong stable stratification of the air layer above, and weaker surface winds (Fig. 5c and 6c). Conversely, turbulent fluxes over the open ocean, or water with a high fraction of leads, acts to intensify the surface winds (Heinemann, 2003). Boundary layer sea-ice effects are also visible in some other model studies which show a substantial weakening of the surface westerlies at high latitudes (Kim et al., 2003). Outside the sea-ice zone, glacial-interglacial changes in all atmospheric boundary conditions have a very similar impact on surface and $850 \mathrm{hPa}$ winds (Fig. 6ab). Whilst prognostic choice will depend on scientific purpose, the above surface (around $850-\mathrm{hPa}$ ) winds may be the most consistent prognostic between models for glacial-interglacial studies of the SH westerlies because they do not suffer from boundary layer effects.

\subsection{The impact of errors in the simulation of Southern Ocean sea surface temperatures}

A second factor, affecting coupled glacial-interglacial modelling studies is errors in simulated pre-industrial Southern Ocean sea surface temperature gradients. This leads to difficulty in interpreting some PMIP2 changes. For 
example, the PMIP2-HadCM3M2 atmosphere-ocean simulation does not feature an enhanced glacial meridional temperature gradient and wind increases in this region (Rojas et al., 2009; Drost et al., 2007). However, this is largely due to overly strong temperature gradients and $\mathrm{SH}$ westerlies in the control pre-industrial simulation (Fig. 1b). Some caution is therefore required in the interpretation of Southern Ocean temperature gradient driven wind changes in these coupled AOGCM simulations.

\section{Simulated and observed moisture changes}

Evaluating model results against the moisture observations offer a unique means to assess the veracity of the simulated glacial-interglacial SH circulation changes (Fig. 7-10). Examination of the the wind and precipitation changes shows that the proposed glacial weakening of the Hadley cell (Williams and Bryan, 2006; Toggweiler and Russell, 2008) occurs in several of the LGM simulations, including the HadAM3 LGM simulation. Glacial easterly winds weaken around $20^{\circ} \mathrm{S}$ in each ocean basin (Fig. 4), and LGM precipitation increases on the west side of South America and South Africa south of $20^{\circ} \mathrm{S}$ (Fig. 7). The reduced Hadley cell strength leads to reduced subsidence related drying around $30^{\circ} \mathrm{S}$. However, contrary to what has been suggested, the weakening of the Hadley cell does not lead to a significant equatorward shift (Toggweiler, 2009; Denton et al., 2010) or to a weakening (Williams and Bryan, 2006; Toggweiler and Russell, 2008) of the westerlies.

\subsection{Interpreting Western Seaboard and wider SH LGM moisture changes}

The local-type match between the annual mean atmospheric-only LGM simulation and observed moisture changes is $100 \%$ on the west of all SH continents. This is important because most paleo-observational interpretations which support a northward shift in the SH westerlies come from western seaboard observations, between these latitudes (Kohfeld et al., submitted). If we more simply restrict the spatial domain to between 35 and $90^{\circ} \mathrm{S}$ (Table 2), the match is $97 \%$. An excellent model-observation match in these regions, without a significant change in winds, provides a strong counter-argument to the hypothesis that an equatorward shift in winds is required to explain these observations.

The general pattern of moisture changes can be described thus. Due to the extended sea-ice and Southern Ocean cooling, the extra-tropical atmosphere cools and reduces the moisture holding capacity of atmosphere above 
the Southern ocean (Fig. 9ac). This extra-tropical drying poleward of $50^{\circ} \mathrm{S}$ occurs in the AGCM and AOGCM LGM simulations (Fig. 7 and 10). Equatorwards, distinct regional patterns emerge from both the observational and model analysis: sites between $30^{\circ} \mathrm{S}$ and $45^{\circ} \mathrm{S}$ in western South America all experienced wetter conditions at the LGM compared to pre-industrial conditions, due to reduced dry air subsidence (Fig. 9d). Sites south of $45^{\circ} \mathrm{S}$ are drier than pre-industrial conditions due to general atmospheric cooling and a reduced moisture retaining capacity (Fig. 9ac 10). In addition to some drying on the central to east regions of the tip South America and Africa, there is also some moistening on the south-west tips of Africa and New Zealand, in both the simulations and in the paleo observations, some of which is related to glacial-ice volume changes (Fig. 9b).

The exact-local type match analysis shows that the atmospheric-only LGM simulation captures $57-83 \%$ of the moisture change observations. The remaining unmatched $17 \%$ of moisture change paleo-observations include geographically closely spaced observations (of various signs) at about $5^{\circ} \mathrm{S}$ in the east of Africa, at $20^{\circ} \mathrm{S}$ on the east coast of South America, and a few from central southern region of Australia. These unmatched observations, from the east or central tropical continental regions, may relate to uncertainties in the tropical zonal gradient changes in our imposed sea surface temperatures (MARGO Project Members, 2009). However, since simply imposing a uniform tropical cooling gives a relatively similar $\mathrm{SH}$ westerlies change pattern (Appendix A), it is unlikely that plausible gradient errors could induce a completely different simulated pattern of LGM SH westerlies.

\subsection{Seasonal moisture and precipitation changes}

Some moisture proxies, such as paleo-vegetation reconstructed from pollen, are likely to reflect seasonal conditions (e.g. Heusser, 1990; Pickett et al., 2004; Williams et al., 2009; Bartlein et al., 2011). Precipitation patterns in parts of the Southern Hemisphere are distinctly seasonal in nature, and the season reflected in the vegetation depends on the region examined (e.g. Williams et al., 2009). Summer precipitation is influenced by southeast trade winds (Gasse and Williamson, 2008; Zech et al., 2009) or the migration of the Intertropical Convergence Zone near the equator (e.g. Barker and Gasse, 2003; Williams et al., 2009), and winter precipitation can be influenced by winter migrations of the modern westerly winds (e.g. Gasse and Williamson, 2008; Lamy et al., 1999; Williams et al., 2009). Thus, it is valid to ask 
whether the LGM moisture patterns inferred from paleo-data could therefore be mainly driven by one particular season, such as wintertime changes influenced by the westerly wind band.

The HadAM3 LGM simulation provides a means to explore which seasonal changes in precipitation patterns contribute to the observed changes in our paleo-moisture reconstruction.

There are distinct changes to the precipitation patterns that persist throughout the year (Fig. 8). However, there are also some seasonal changes. In zones influenced by the modern-day westerlies band, all seasons show enhanced precipitation along the west coasts of South America and Africa during the LGM, but the latitudes of enhanced precipitation can depend on season. The overall effect is that the mean annual conditions show higher precipitation all along the west coasts of these continents during the LGM, and thus provide a better match to the data than individual seasons. In contrast, the simulated LGM increases in precipitation off southern Australia and southern New Zealand are more seasonal, occurring predominantly in austral autumn and winter. In this case, the increased winter precipitation is not enough to offset the strength of the summer drying in the model. This could decrease the coherence between the simulated mean annual precipitation and observations.

Overall we find that the simulated mean annual conditions provide a better match to the paleo-proxy data than simulated conditions for any particular season. It is possible that this is because the spatial extent of our comparison covers regions in which different seasonal precipitation regimes dominate, and the simulated mean annual precipitation is best able to integrate the net changes seen in all of these regions. When the exact match model-data agreement metrics are calculated for these individual seasons we find that the match is: $57 \%$ for the annual mean; $57 \%$ for the austral summer (DJF); $55 \%$ for the austral autumn (MAM); $30 \%$ for austral winter (JJA); and $47 \%$ for austral spring (SON) (see also Fig. 7). This suggests that it will usually be more robust to use mean annual, rather than any individual single season, results when testing LGM model simulations against the Kohfeld et al. (submitted) moisture database. Finally, we note that given the oceanwind carbon hypothesis is constructed in terms of mean annual wind changes, it is perhaps reassuring that the model-data match to the glacial-interglacial moisture reconstruction is highest for mean annual conditions. 


\subsection{Hadley Cell induced changes}

The sub-tropical moistening across each continent is related to the tropical sea surface changes (Fig. 9d), and an associated weakening of the Hadley cell strength. Fig. 9-10, alongside Table 1 and Appendices A, show that simulations which feature the weakening of the Hadley cell strength, tend to have the strongest model-observation agreements. None of the simulations which feature this change in the Hadley Cell strength feature a significant equatorwards shift in the LGM SH westerlies.

Results from coupled ocean-atmosphere glacial PMIP2 simulations (Table 1) indicate that two AOGCMs, HadCM3M2 and MIROC3.2.2, also have good matches of at least 53-70\% (exact-local) to observed glacial-interglacial moisture change. In common with the atmospheric only simulations, the Hadley cell weakens in these simulations. Two other AOGCM simulations feature lower model-observational scores of 44-63\% (exact-local) and show little or no reduction in Hadley cell strength. These less good matches to observations suggest that these atmospheric simulations are less likely correct in the SH. This PMIP2 data-model comparison supports the idea that that the glacial Hadley cell was reduced in strength, but that the reduction was not associated with a large (greater than $2^{\circ}$ ) latitudinal shift in the position of the westerly wind band.

\section{Discussion of relation of results to a wider set of paleo-environmental evidence}

The section above indicates that LGM moisture changes, which comprise the bulk of the available LGM Southern Hemisphere paleo-enviromental atmospheric change evidence (Kohfeld et al., submitted), can be explained without a strengthening of westerly winds, except over the southerly areas of the Southern Ocean. However, Kohfeld et al. (submitted) also discusses and compiles other types of data which indicate LGM paleo-enviromental changes. Whilst many of these observed changes were found to be too difficult to interpret as evidence which might support any wind change hypothesis, here we nevertheless briefly discuss the implications of dust and ocean front evidence in the context of our simulated LGM Southern Hemisphere wind and moisture changes. 


\subsection{Observed LGM dust changes}

One piece of paleo-enviromental evidence which has previously interpreted in terms of wind changes, is the enhanced dust fluxes to the ocean surface and Antarctic continent during the LGM. Several factors could contribute to greater dust: expanded source areas, reduced entrainment thresholds (due to moisture reductions), stronger winds over these source regions, greater residence times of dust, and increased transport lengths (due to increased wind strengths). Although using a dust cycle model is beyond the scope of this work, the LGM simulation shows drying in the areas we associate with LGM dust entrainment (Patagonia and shelf areas; Australia, southern Africa; Fig. 7). Furthermore, stronger winds in the modern-day Antarctic Circumpolar Current region and a drier atmosphere over much of the Antarctic region (Fig. 4c and Fig. 7) suggest that the transport lengths, and atmospheric residence time for dust, may have increased facilitating greater amounts of dust transport to the Southern Ocean and Antarctica. In addition, a lower LGM sea-level exposed more continental shelf, which would have increased the potential dust source region size. Thus it is possible that the LGM atmospheric changes simulated here are in agreement with observed LGM dust flux changes.

\subsection{Observed ocean front changes: The Southern Ocean and the Agulhus Current}

On the position of Southern Ocean fronts, previous studies have argued that equatorward shifts in these fronts may indicate an equatorward shift of the westerly winds at the LGM (Howard and Prell, 1992; Kohfeld et al., submitted). This question cannot be addressed using our atmospheric simulations since the HadAM3 model use ocean surface conditions as an input. The PMIP2 coupled simulations are also incapable of addressing this question because their oceanic model components have a resolution too coarse to resolve individual oceanic fronts. However, as a general comment on this, Kohfeld et al. (submitted) both shows that the position of these fronts at the LGM is presently under constrained in most sectors of the Southern Ocean, and suggests that the nature of the relationship between winds and fronts is also quite poorly understood.

Available paleo-evidence for the strength of the Southern Ocean Antarctic Circumpolar Current (ACC) suggest that during the LGM it could either be stronger than today (Noble et al., 2012) or of similar intensity (McCave and Kuhn, 2012). If the ACC was a wind-driven current the observations 
also indicate similar or stronger $\mathrm{SH}$ westerlies. However, this interpretation is too simplistic because the ACC is now thought to be driven by both buoyancy and wind forcing (Hogg, 2010; Allison et al., 2010; Munday et al., 2011) . Recent oceanic modelling has also shown that significant changes in ACC transport occur when diapycnal mixing changes in far-field sites ocean basin (Munday et al., 2011), and such mixing changes have been proposed for the LGM in response to sea level lowering (Wunsch, 2003). Thus, it is probably not currently possible to draw any useful conclusion about whether our simulated winds are in agreement with the LGM ACC strength.

We also note that LGM changes in Southern Ocean water masses and ocean productivity cannot easily be interpreted in terms of wind changes (Kohfeld et al., submitted).

Outside the Southern Ocean, a number of studies have indicated that the volume of Agulhas Leakage was probably reduced during glacial periods (Flores et al., 1999, 2003). It has been hypothesized that this is due to an equatorward shift of the westerly wind belt and Subtropical Front (Bard and Rickaby, 2009). However, a reduction in Agulhas Leakage may also be caused by increased wind stress at the southern tip of South Africa, increasing the wind stress curl over the subtropical gyre circulation in the Indian Basin (Beal et al., 2011). Consistent with this particular hypothesis, our LGM simulation shows increased wind speeds over this region.

\section{Conclusions and implications for glacial winds}

Whilst Southern Hemisphere (SH) westerly winds are thought to be critical to global ocean circulation, productivity, and carbon storage, it is currently not clear, from observations or model results, how they behave during the last glacial (Kohfeld et al., submitted). Here we performed a set of atmospheric model simulations, including sensitivity simulations to examine the impact of individual LGM boundary condition changes. We examined the Southern Hemisphere westerly wind changes which occur as a result of these boundary changes. Additionally, we compare both these simulations, and PMIP2 coupled AOGCM simulations, with the new Kohfeld et al. (submitted) synthesised moisture database.

In our main atmospheric-only LGM simulation, the $\mathrm{SH}$ westerlies are strengthened by $\sim+1 \mathrm{~ms}^{-1}$ and moved southward by $\sim 2^{\circ}$ at the $850 \mathrm{hPa}$ pressure level. However, boundary layer stabilisation effects over equatorward extended LGM sea-ice can lead to a small apparent equatorward shift 
in the wind band at the surface. It is likely that this boundary layer effect, due to extended LGM sea-ice, is one reason why some previous model studies have suggested an equatorward shift in SH westerly winds. Thus the impact of the choice of wind prognostic can lead to a divergence in the the apparent $\mathrm{SH}$ westerly wind changes.

Interestingly, we find here that a reduction in Hadley Cell strength does not equate to an equatorward shift of the westerlies. However, the weakening does result in a wetting of the usually dry subsidence regions, which we find can explain most of the observed LGM SH moisture changes. It also appears to be more robust to use mean annual, rather than individual single season, results when testing LGM model simulations against the Kohfeld et al. (submitted) moisture database.

Our data-model comparison suggests that glacial-interglacial changes in atmospheric circulation are being simulated with a relatively good accuracy, according to the available atmospheric observational constraints. The HadAM3 LGM simulation, which shows small poleward wind shift, produces the best fit with the moisture proxy data. This implies that current models perform quite well at capturing these paleo-environmental changes. As a result, whilst this does not fully exclude the possibility that an equatorward shift of the westerlies could result in moister conditions around $40^{\circ} \mathrm{S}$, we conclude there is no direct evidence in moisture change observations for any equatorward shift in the $\mathrm{SH}$ wind band. Our model experiments are carried out at a resolution of $2.5^{\circ} \times 3.75^{\circ}$. Finer model resolutions can improve the representation of Southern Hemisphere winds (e.g. Matsueda et al., 2010), thus it is possible that a better simulation of the observed moisture and wind changes may be possible using models run at higher resolutions.

Whilst the wind changes simulated here seem to be in good agreement with observed LGM moisture changes, and may also be in agreement with observed LGM-dust trends, it has not been possible here for us to test the wind changes against observed LGM ocean front data. Recent ocean modelling work (e.g. Section 5.2) has again highlighted the difficulty in interpreting the LGM ocean changes from sparse observations (Wunsch, 2003). Thus it is probably not presently possible to discern if our simulated atmospheric changes may be in agreement with oceanic observations. A detailed high resolution ocean and biogeochemical modelling study might be one possible avenue to attempt to explore this intriguing question.

In terms of the implications for the longer Quaternary record of atmosphere $\mathrm{CO}_{2}$ changes, cold glacial periods other than the LGM have insuffi- 
cient paleoclimate observations (sea surface conditions and moisture changes) with which to make a similar SH westerly wind assessment. However, additional sensitivity experiments, in which sea surface temperature patterns and gradients are changed (temperature reductions of between 1 and $4^{\circ} \mathrm{C}$ ), suggest that the maximum equatorward shift in the wind band that can be induced is about $3^{\circ}$ (Appendix A). This is much smaller than the 7-10 degree shift of wind hypothesised for the LGM which was posited as the cause of the observed rise in atmospheric $\mathrm{CO}_{2}$ into the Holocene (Toggweiler et al., 2006).

In summary, although Kohfeld et al. (submitted) shows that observational evidence has most often been interpreted as indicating a 3 to $15^{\circ} \mathrm{LGM}$ equatorward shift in SH westerly winds, the synthesis of LGM paleo-environmental change evidence and discussion of it's interpretation suggests that there is no unambiguous observation evidence which supports the shift idea. The broad analysis of GCM behaviour presented here suggests that an equatorward $\mathrm{SH}$ westerly wind shift of more than $3^{\circ}$ may be unlikely. Although we cannot prove here that a large equatorward shift would not be able to reproduce the moisture data as well, we have shown here that the moisture proxies do not provide an observational evidence base for it.

\section{Acknowledgements}

PMIP2 for their role in making available the multi-model dataset; and William Connolley for assistance with model setup. It was funded by The Natural Environment Research Council and forms a part of the British Antarctic Survey Polar Science for Planet Earth Programme.

\section{References}

Allison, L.C., Johnson, H.L., Marshall, D.P., Munday, D.R., 2010. Where do winds drive the Antarctic Circumpolar Current? Geophysical Research Letters 37, L12605+.

Bard, E., Rickaby, R.E.M., 2009. Migration of the subtropical front as a modulator of glacial climate. Nature 460, 380-383.

Barker, P., Gasse, F., 2003. New evidence for a reduced water balance in east africa during the last glacial maximum: implication for model-data comparison. Quaternary Science Reviews 22, 823-837. 
Bartlein, P.J., Harrison, S.P., Brewer, S., Connor, S., Davis, B.A.S., Gajewski, K., Guiot, J., Harrison-Prentice, T.I., Henderson, A., Peyron, O., Prentice, I.C., Scholze, M., Seppä, H., Shuman, B., Sugita, S., Thompson, R.S., Viau, A.E., Williams, J., Wu, H., 2011. Pollen-based continental climate reconstructions at 6 and 21ka: a global synthesis. Climate Dynamics $37,775-802$.

Beal, L.M., De Ruijter, W.P.M., Biastoch, A., Zahn, R., 2011. On the role of the Agulhas system in ocean circulation and climate. Nature 472, 429-436.

Braconnot, P., Harrison, S.P., Kageyama, M., Bartlein, P.J., MassonDelmotte, V., Abe-Ouchi, A., Otto-Bliesner, B., Zhao, Y., 2012. Evaluation of climate models using palaeoclimatic data. Nature Clim. Change $2,417-424$.

Braconnot, P., Otto-Bliesner, B., Harrison, S., Joussaume, S., Peterchmitt, J.Y., Abe-Ouchi, A., Crucifix, M., Driesschaert, E., Fichefet, T., Hewitt, C.D., Kageyama, M., Kitoh, A.; Laîné, A., Loutre, M.F., Marti, O., Merkel, U., Ramstein, G., Valdes, P., Weber, S.L., Yu, Y., Zhao, Y., 2007. Results of PMIP2 coupled simulations of the Mid-Holocene and Last Glacial Maximum - Part 1: Experiments and large-scale features. Climate of the Past 3, 261-277.

Caley, T., Giraudeau, J., Malaizé, B., Rossignol, L., Pierre, C., 2012. Agulhas leakage as a key process in the modes of Quaternary climate changes. Proceedings of the National Academy of Sciences .

Collins, M., Tett, S.F.B., Cooper, C., 2001. The internal climate variability of HadCM3, a version of the Hadley Centre coupled model without flux adjustments. Climate Dynamics 17, 61-81.

De Boer, A.M., Nof, D., 2005. The island wind-buoyancy connection. Tellus A 57, 783-797.

De Boer, A.M., Toggweiler, J.R., Sigman, D.M., 2008. Atlantic Dominance of the Meridional Overturning Circulation. J. Phys. Oceanogr. 38, 435-450.

De Boer, A.M., Watson, A.J., Edwards, N.R., Oliver, K.I.C., 2010. A comprehensive, multi-process box-model approach to glacial-interglacial carbon cycling. Climate of the Past Discussions 6, 867-903. 
Denton, G.H., Anderson, R.F., Toggweiler, J.R., Edwards, R.L., Schaefer, J.M., Putnam, A.E., 2010. The last glacial termination. Science 328, $1652-1656$.

Drost, F., Renwick, J.A., Bhaskaran, B., Oliver, H., McGregor, J., 2007. Features of the zonal mean circulation in the Southern Hemisphere during the Last Glacial Maximum. J. Geophys. Res. 112.

Flores, J.A., Gersonde, R., Sierro, 1999. Pleistocene fluctuations in the agulhas current retroflection based on the calcareous plankton record. Marine Micropaleontology 37, 1-22.

Flores, J.A., Marino, M., Sierro, F.J., Hodell, D.A., Charles, C.D., 2003. Calcareous plankton dissolution pattern and coccolithophore assemblages during the last $600 \mathrm{kyr}$ at ODP site 1089 (cape basin, south atlantic): paleoceanographic implications. Palaeogeography, Palaeoclimatology, Palaeoecology 196, 409-426.

Gasse, F., C.F.V.A.W.M., Williamson, D., 2008. Climatic patterns in equatorial and southern africa from 30,000 to 10,000 years ago reconstructed from terrestrial and near-shore proxy data. Quaternary Science Reviews $27,2316-2340$.

Gersonde, R., Crosta, X., Abelmann, A., Armand, L., 2005. Sea surface temperature and sea ice distribution of the last glacial. Southern Ocean A circum-Antarctic view based on siliceous microfossil records. Quaternary Science Reviews 24, 869-896.

Gordon, C., Cooper, C., Senior, C.A., Banks, H., Gregory, J.M., Johns, T.C., Mitchell, J.F.B., Wood, R.A., 2000. The simulation of SST, sea ice extents and ocean heat transports in a version of the Hadley Centre coupled model without flux adjustments. Climate Dynamics 16, 147-168.

Heinemann, G., 2003. Forcing and feedback mechanisms between the katabatic wind and sea ice in the coastal areas of polar ice sheets. The Global Atmosphere-Ocean System 9, 169-201.

Heusser, C., 1989. Southern westerlies during the last glacial maximum. Journal of Quaternary Science 31, 423-425. 
Heusser, C., 1990. Ice-age vegetation and climate of subtropical chile. Palaeogeography Palaeoclimatology Palaeoecology 80, 107-127.

Hogg, A.M., 2010. An Antarctic Circumpolar Current driven by surface buoyancy forcing. Geophysical Research Letters 37, L23601+.

Howard, W.R., Prell, W.L., 1992. Late Quaternary Surface Circulation of the Southern Indian Ocean and its Relationship to Orbital Variations. Paleoceanography 7.

Kim, S., Flato, G., Boer, G., 2003. A coupled climate model simulation of the Last Glacial Maximum, Part 2: approach to equilibrium. Climate Dynamics 20, 635-661.

Kim, S., Flato, G., Boer, G., McFarlane, N., 2002. A coupled climate model simulation of the Last Glacial Maximum, Part 1: transient multi-decadal response. Climate Dynamics 19, 515-537.

Kitoh, A., Murakami, S., Koide, H., 2001. A simulation of the Last Glacial Maximum with a coupled atmosphere-ocean GCM. Geophysical Research Letters 28, 2221-2224.

Kohfeld, K., Graham, R., de Boer, A., Sime, L., Wolff, E., Le Quéré, C., Bopp, L., submitted. Southern hemisphere westerly wind changes during the last glacial maximum: Paleo-data synthesis. Quaternary Science Reviews, - .

Kohfeld, K.E., Quere, C.L., Harrison, S.P., Anderson, R.F., 2005. Role of Marine Biology in Glacial-Interglacial CO2 Cycles. Science 308, 74-78. http://www. sciencemag.org/cgi/reprint/308/5718/74.pdf.

Lachlan-Cope, T.A., Connolley, W.M., Turner, J., 2007. Effects of tropical sea surface temperature (SST) errors on the Antarctic atmospheric circulation of HadCM3. Geophysical Research Letters 34.

Lamy, F., Hebbeln, D., Wefer, G., 1999. High-resolution marine record of climatic change in mid-latitude chile during the last 28,000 years based on terrigenous sediment parameters. Quaternary Research 51, 83-93.

Laskar, J., Robutel, P., Joutel, F., Gastineau, M., Correia, A., Levrard, B., 2004. A long term numerical solution for the insolation quantities of the Earth. Astronomy and Astrophysics 428, 261-285. 
Le Quéré, C., Rödenbeck, C., Buitenhuis, E.T., Conway, T.J., R., L., Gomez, A., Labuschagne, C., Ramonet, M., Nakazawa, T., Metzl, N., Gillett, N., Heimann, M., 2007. Saturation of the Southern Ocean $\mathrm{CO}_{2}$ sink due to recent climate change. Science 316, 1735-1738.

Levermann, A., Schewe, J., Montoya, M., 2007. Lack of bipolar see-saw in response to Southern Ocean wind reduction. Geophysical Research letters 34 .

MARGO Project Members, 2009. Constraints on the magnitude and patterns of ocean cooling at the Last Glacial Maximum. Nature Geoscience 2, 127132.

Marshall, G.J., Connolley, W.M., 2006. Effect of changing Southern Hemisphere winter sea surface temperature on Southern Annular Mode strength. Geophysical Research Letters 33.

Masson-Delmotte, V., Kageyama, M., Braconnot, P., Charbit, S., Krinner, G., Ritz, C., Guilyardi, E., Jouzel, J., Abe-Ouchi, A., Crucifix, M., Gladstone, R., Hewitt, C., Kitoh, A., LeGrande, A., Marti, O., Merkel, U., Motoi, T., Ohgaito, R., Otto-Bliesner, B., Peltier, W., Ross, I., Valdes, P., Vettoretti, G., Weber, S., Wolk, F., Yu, Y., 2006. Past and future polar amplification of climate change: climate model intercomparisons and ice-core constraints. Climate Dynamics 26, 513-529.

Matsueda, M., Endo, H., Mizuta, R., 2010. Future change in southern hemisphere summertime and wintertime atmospheric blockings simulated using a 20-km-mesh AGCM. Geophysical Research Letters 37, L02803+.

McCave, I.N., C.S.H.C.D., Kuhn, G., 2012. Constant flow speed of the ACC through Drake Passage between glacial maximum and Holocene. European Geophysical Union, publisher=Vienna, Austria, doi=EGU2012-9842, note $=$ EGU2012-9842, .

Menviel, L., Timmermann, A., Mouchet, A., Timm, O., 2008. Climate and marine carbon cycle response to changes in the strength of the Southern Hemispheric westerlies. Paleoceanography 23, PA4201.

Moreno, P.I., Lowell, T.V., Jacobson Jr, G.L., Denton, G.H., 1999. Abrupt vegetation and climate changes during the Last Glacial Maximum and last 
termination in the Chilean Lake District: A case study from Canal de la Puntilla (41s). Geografiska annaler, Series A 81, 285-311.

Munday, D.R., Allison, L.C., Johnson, H.L., Marshall, D.P., 2011. Remote forcing of the Antarctic Circumpolar Current by diapycnal mixing. Geophysical Research Letters 38, L08609+.

Noble, T.L., Piotrowski, A.M., Robinson, L.F., McManus, J.F., Hillenbrand, C.D., Bory, A.J.M., 2012. Greater supply of Patagonian-sourced detritus and transport by the ACC to the Atlantic sector of the Southern Ocean during the last glacial period. Earth and Planetary Science Letters 317318, 374-385.

Nof, D., De Boer, A.M., 2004. From the Southern Ocean to the North Atlantic in the Ekman Layer? Bull. Amer. Meteor. Soc. 85, 79-87.

Otto-Bliesner, B.L., Brady, E., Clauzet, G., Thomas, R., Levis, S., Kothavala, Z., 2006. Last glacial maximum and Holocene climate in CCSM3. Journal of Climate 19, 2526-2544.

Parish, T.R., Bromwich, D.H., Tzeng, R.Y., 1994. On the Role of the Antarctic Continent in Forcing Large-Scale Circulations in the High Southern Latitudes. Journal of the Atmospheric Sciences 51, 3566-3579.

Parrenin, F., Dreyfus, G., Durand, G., Fujita, S., Gagliardini, O., Gillet, F., Jouzel, J., Kawamura, K., Lhomme, N., Masson-Delmotte, V., Ritz, C., Schwander, J., Shoji, H., Uemura, R., Watanabe, O., Yoshida, N., 2007. 1-D-ice flow modelling at EPICA Dome C and Dome Fuji, East Antarctica. Climate of the Past 3, 243-259.

Paul, A., Schäfer-Neth, C., 2003a. Gridded Global LGM SST and Salinity Reconstruction, IGBP PAGES/World Data Center for Paleoclimatology, Boulder Data Contribution Series 2003-046 NOAA/NGDC Paleoclimatology Program, Boulder CO, USA. ,- .

Paul, A., Schäfer-Neth, C., 2003b. Modeling the water masses of the Atlantic Ocean at the Last Glacial Maximum. Paleoceanography 18.

Peltier, W., 2004. Global Glacial Isostasy and the Surface of the Ice-Age Earth: The ICE-5G(VM2) model and GRACE. Ann Rev Earth Planet Sci 32, 111-149. 
Pickett, E.J., Harrison, S.P., Hope, G., Harle, K., Dodson, J.R., Peter Kershaw, A., Colin Prentice, I., Backhouse, J., Colhoun, E.A., D'Costa, D., Flenley, J., Grindrod, J., Haberle, S., Hassell, C., Kenyon, C., Macphail, M., Martin, H., Martin, A.H., McKenzie, M., Newsome, J.C., Penny, D., Powell, J., Ian Raine, J., Southern, W., Stevenson, J., Sutra, J.P., Thomas, I., Kaars, S., Ward, J., 2004. Pollen-based reconstructions of biome distributions for australia, southeast asia and the pacific (seapac region) at 0 , 6000 and 18,000 14c yr bp. Journal of Biogeography, 1381-1444.

Pope, V.D., Gallani, M.L., Rowntree, P.R., Stratton, R.A., 2000. The impact of new physical parametrizations in the Hadley Centre climate model: HadAM3. Climate Dynamics 16, 123-146.

Rahmstorf, S., England, M.H., 1997. Influence of Southern Hemisphere Winds on North Atlantic Deep Water Flow. J. Phys. Oceanogr. 27, 20402054.

Rayner, N.A., Parker, D.E., Horton, E.B., Folland, C.K., Alexander, L.V., P., R.D., 2003. Global analyses of sea surface temperature, sea ice, and night marine air temperature since the late nineteenth century. Journal of Geophysical Research 108.

Rojas, M., Moreno, P., Kageyama, M., Crucifix, M., Hewitt, C., Abe-Ouchi, A., Ohgaito, R., Brady, E., Hope, P., 2009. The Southern Westerlies during the last glacial maximum in PMIP2 simulations. Climate Dynamics 32, $525-548$.

Russell, J.L., Stouffer, R.J., Dixon, K.W., 2006. Intercomparison of the Southern Ocean circulations in the IPCC coupled model control simulations. Journal of Climate 19, 4560-4575.

Shin, S.I., Liu, Z., Otto-Bliesner, B., Brady, E., Kutzbach, J., Harrison, S., 2003. A Simulation of the Last Glacial Maximum climate using the NCAR-CCSM. Climate Dynamics 20, 127-151.

Shindell, D., Schmidt, G., 2004. Southern hemisphere climate response to ozone changes and greenhouse gas increases. Geophysical Research Letters L18209.

Sigman, D.M., Boyle, E.A., 2000. Glacial/interglacial variations in atmospheric carbon dioxide. Nature , 859-869. 
Sigman, D.M., Hain, M.P., Haug, G.H., 2010. The polar ocean and glacial cycles in atmospheric co2 concentration. Nature 466, 47-55.

Sijp, W.P., England, M.H., 2009. Southern Hemisphere Westerly Wind Control over the Ocean's Thermohaline Circulation. J. Climate 22, 1277-1286.

Sime, L., Stevens, D., Heywood, K., Oliver, K., 2006. A Decomposition of the Atlantic Meridional Overturning. Journal of Physical Oceanography 36,22532270 .

Skinner, L.C., Fallon, S., Waelbroeck, C., Michel, E., Barker, S., 2010. Ventilation of the deep southern ocean and deglacial co2 rise. Science 328, $1147-1151$.

Toggweiler, J.R., 1999. Variation of atmospheric $\mathrm{CO}_{2}$ by ventilation of the ocean's deepest water. Paleoceanography 14, 571-588.

Toggweiler, J.R., 2009. Shifting westerlies. Science 323, 1434-1435.

Toggweiler, J.R., Russell, J., 2008. Ocean circulation in a warming climate. Nature 451, 286-288.

Toggweiler, J.R., Russell, J., Carson, S.R., 2006. Midlatitude westerlies, atmospheric $\mathrm{CO}_{2}$, and climate change during the ice ages. Paleoceanography 21.

Toggweiler, J.R., Samuels, B., 1993. The Global Carbon Cycle. SpringerVerlag. chapter Is the magnitude of the deep outflow from the Atlantic Ocean actually governed by Southern Hemisphere winds? pp. 303-331.

Toggweiler, J.R., Samuels, B., 1995. Effect of Drake Passage on the global thermohaline circulation. Deep-Sea Research I 42, 477-500.

Toggweiler, J.R., Samuels, B., 1998. On the ocean's large-scale circulation near the limit of no vertical mixing. Journal of Physical Oceanography 28, $1832-1852$.

Watson, A.J., Naveira Garabato, A.C., 2006. The role of Southern Ocean mixing and upwelling in glacial-interglacial atmospheric $\mathrm{CO}_{2}$ change. Tellus $58,73-87$. 
Williams, G., Bryan, K., 2006. Ice Age Winds: An Aquaplanet Model. Journal of Climate 19, 17061715.

Williams, M., Cook, E., van der Kaars, S., Barrows, T., Shulmeister, J., Kershaw, P., 2009. Glacial and deglacial climatic patterns in Australia and surrounding regions from 35000 to 10000 years ago reconstructed from terrestrial and near-shore proxy data. Quaternary Science Reviews 28, 2398-2419.

Wunsch, C., 2003. Determining paleoceanographic circulations, with emphasis on the Last Glacial Maximum. Quaternary Science Reviews 22, $371-385$.

Wyrwoll, K.H., Dong, B.W., Valdes, P., 2000. On the position of southern hemisphere westerlies at the Last Glacial Maximum: an outline of AGCM simulation results and evaluation of their implications. Quaternary Science Reviews 19.

Yin, J.H., Battisti, D.S., 2001. The importance of tropical sea surface temperature patterns in simulations of last glacial maximum climate. Journal of Climate 14, 565-581.

Zech, M., Zech, R., Morrás, H., Moretti, L., Glaser, B., Zech, W., 2009. Late quaternary environmental changes in misiones, subtropical NE argentina, deduced from multi-proxy geochemical analyses in a palaeosol-sediment sequence. Quaternary International 196, 121-136. 
988 


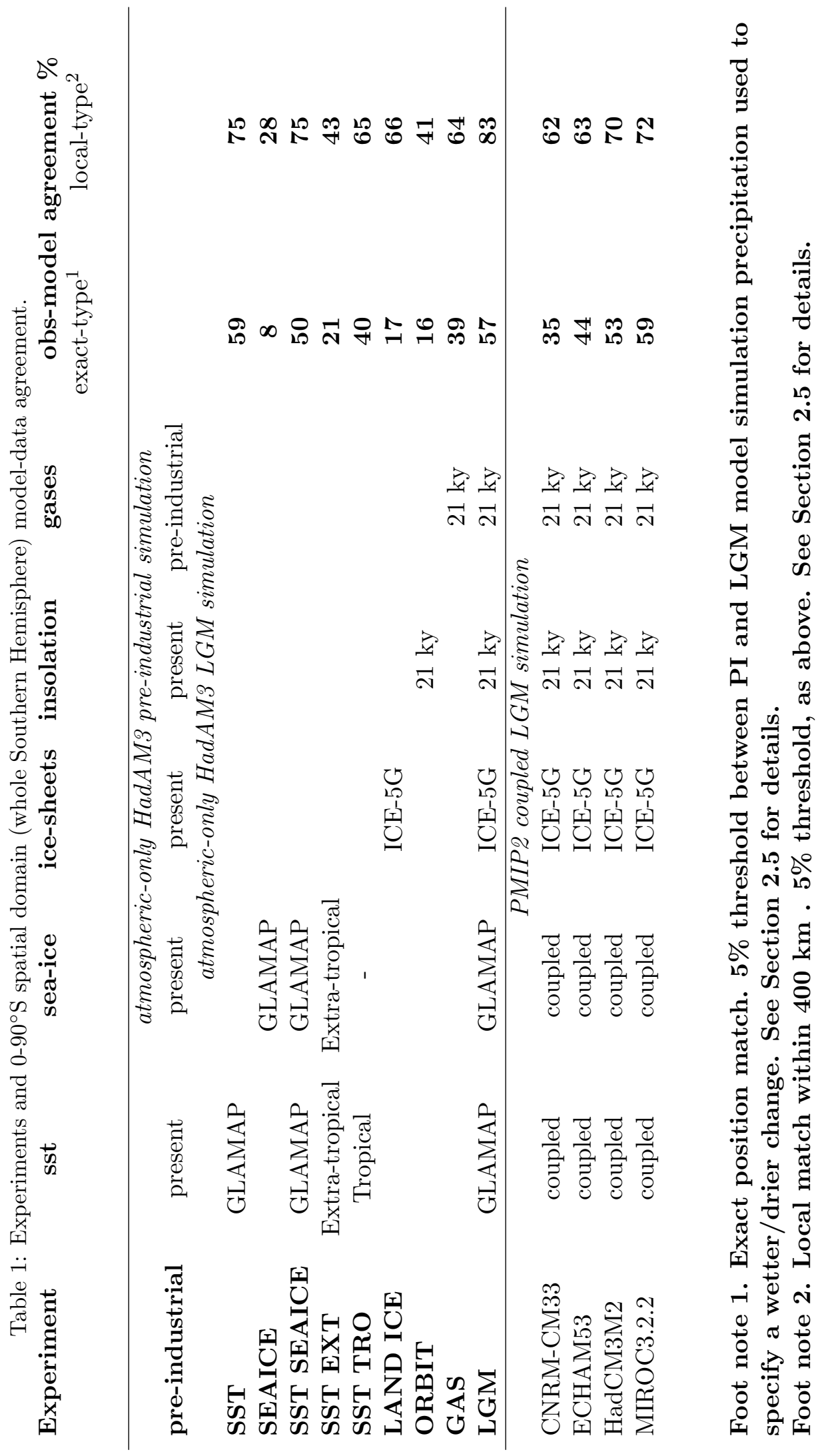




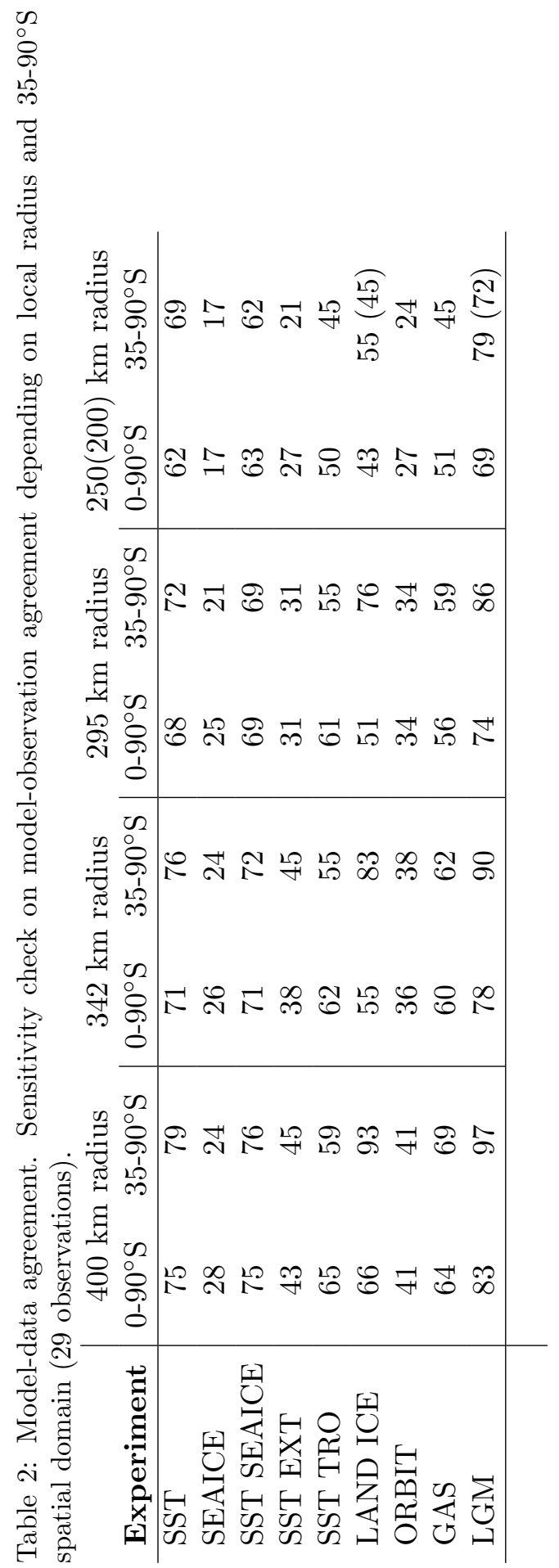




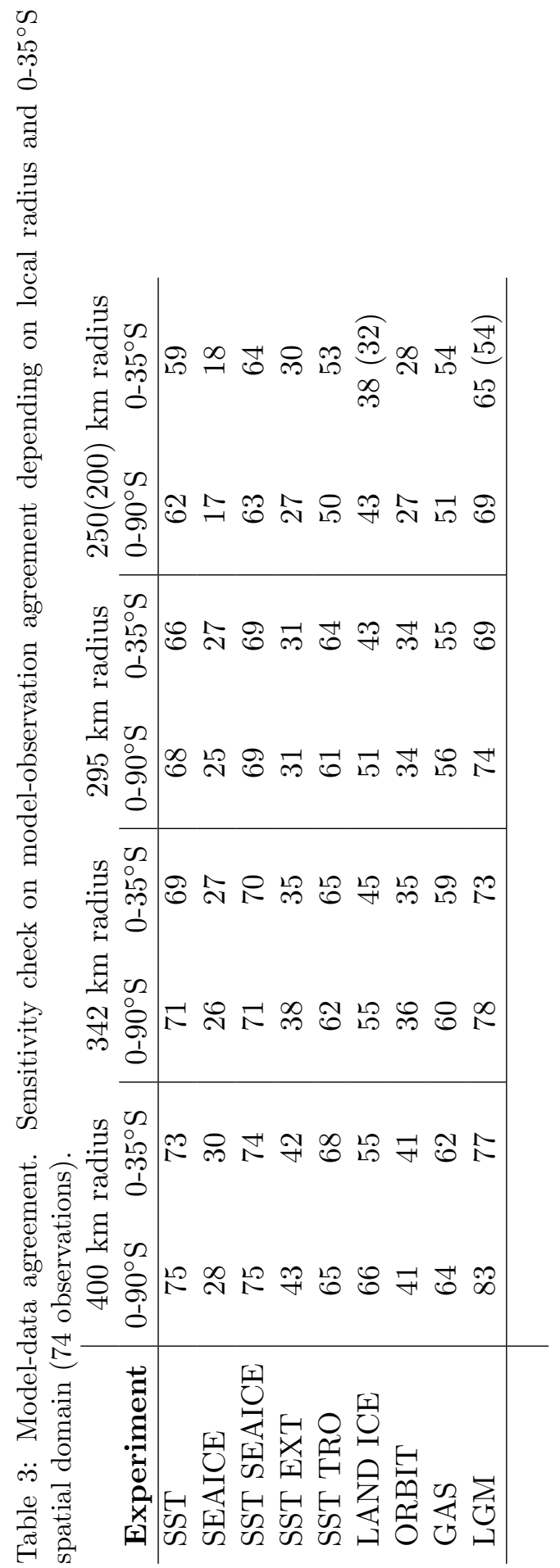



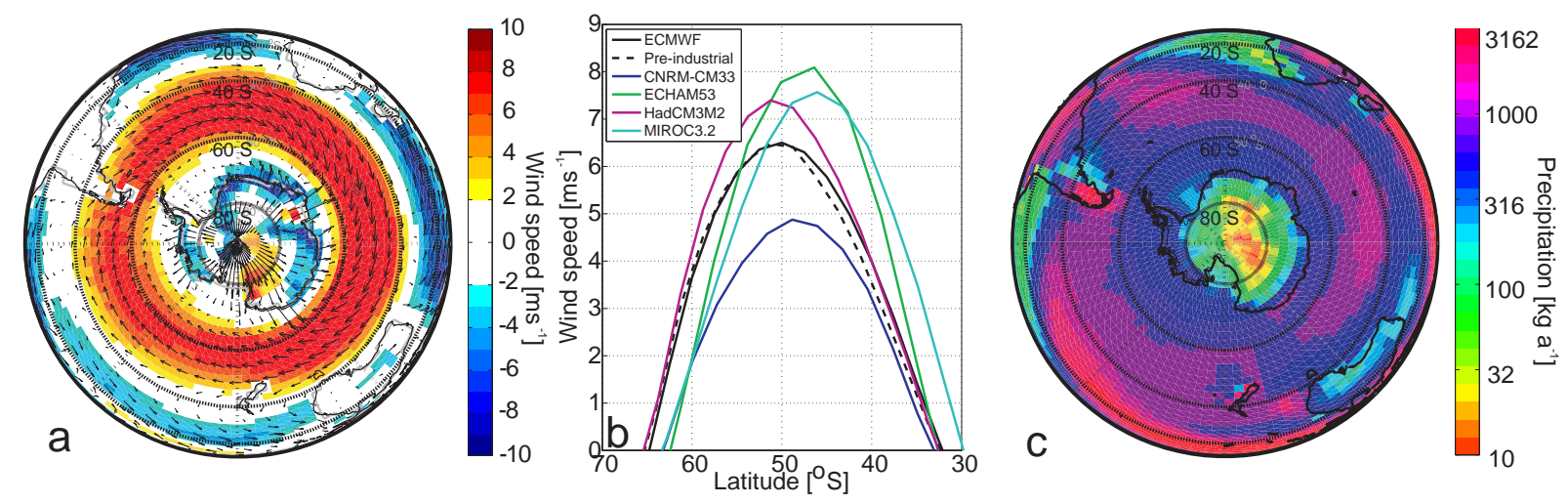

Figure 1: (a) Annual mean surface $(10 \mathrm{~m})$ westerly wind speed $\left(\mathrm{m} \mathrm{s}^{-1}\right)$ for the preindustrial simulation. Arrows show wind velocity. (b) The zonal mean annual mean surface $(10 \mathrm{~m})$ westerly wind speed from the HadAM3 (pre-industrial) and ECMWFERA40 reanalysis; alongside results from each PMIP2 pre-industrial (control) experiment (as noted on legend). (c) Annual mean precipitation $\left(\mathrm{mm} \mathrm{yr}^{-1}\right)$ for the pre-industrial simulation on a logarithmic colour-scale.
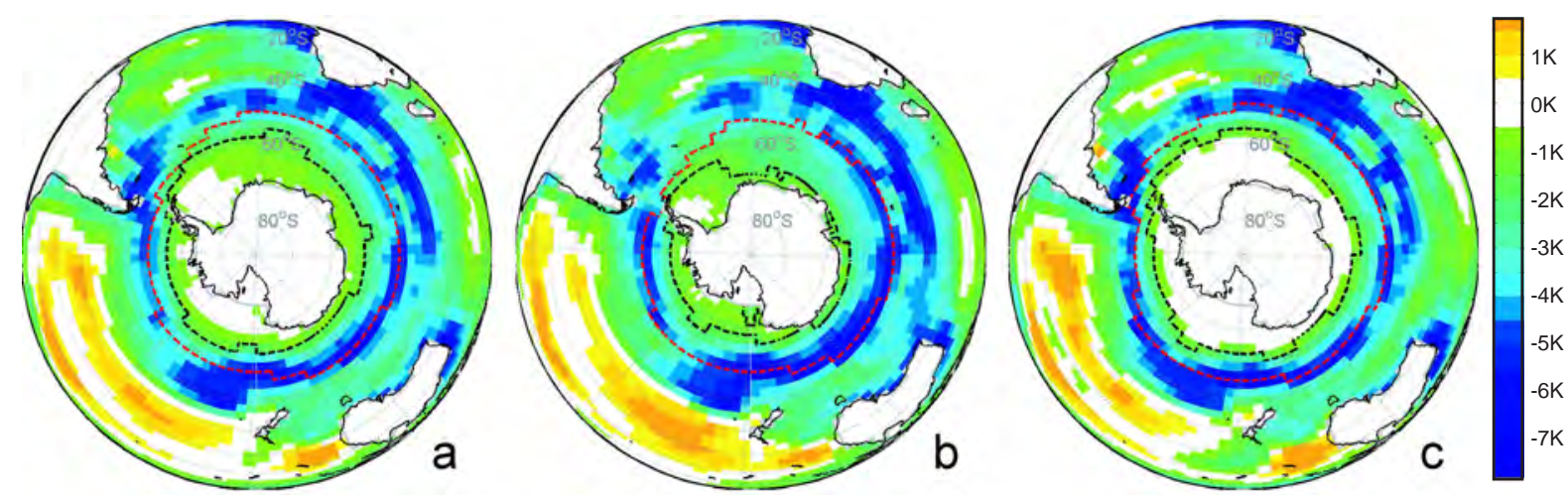

Figure 2: Shading shows the sea surface temperature anomaly $(\mathrm{K})$ obtained by differencing GLAMAP LGM from a twenty year mean of present day HadiSST temperatures (19801999) for (a) annual, (b) austral summer, and (c) austral winter conditions. Dashed lines show the $50 \%$ sea-ice concentration boundaries for GLAMAP in red and present day in black. 


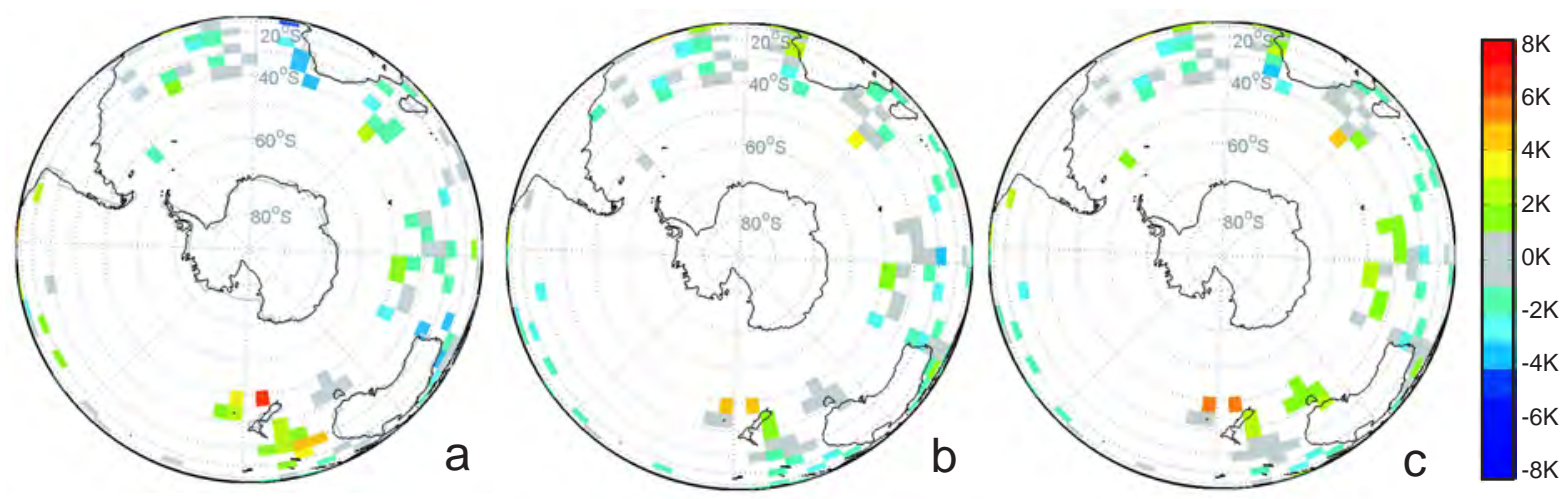

Figure 3: Shading shows the (a) annual mean GLAMAP; (b) PMIP2 HadCM3; and (c) PMIP2 MIROC3.2; each minus the MARGO LGM sea surface temperatures observations. Results are plotted for the $5 \times 5$ deg grid positions where MARGO observations are available. Grey shows a difference of less than $1 \mathrm{~K}$, white shows regions where no MARGO data exists. 


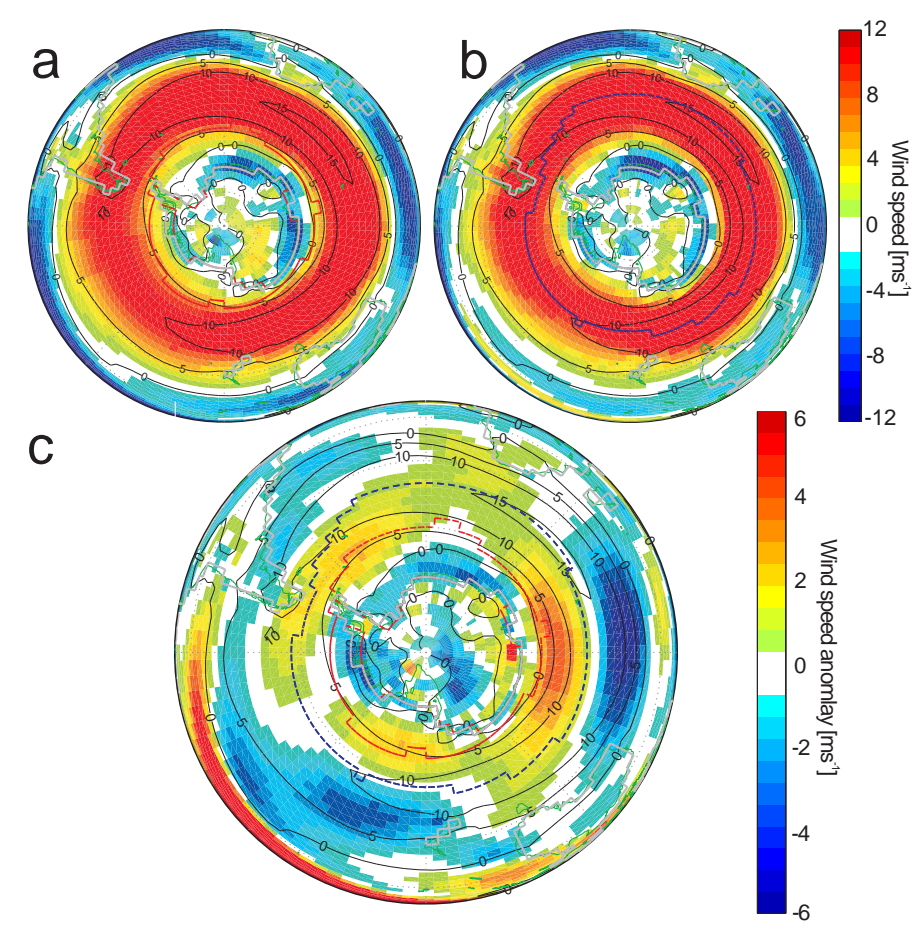

Figure 4: Changes between simulated pre-industrial and glacial Southern Hemisphere westerlies. Shading on panel (a) shows pre-industrial and (b) LGM $850 \mathrm{hPa}$ mean annual westerly wind speed. Shading on panel (c) shows LGM minus pre-industrial $850 \mathrm{hPa}$ wind speed. Red (blue) dashes on each panel show the pre-industrial (LGM) $50 \%$ seaice edge. To facilitate inter-simulation wind comparison, black contours on each panel indicate simulated pre-industrial westerly wind speed. 

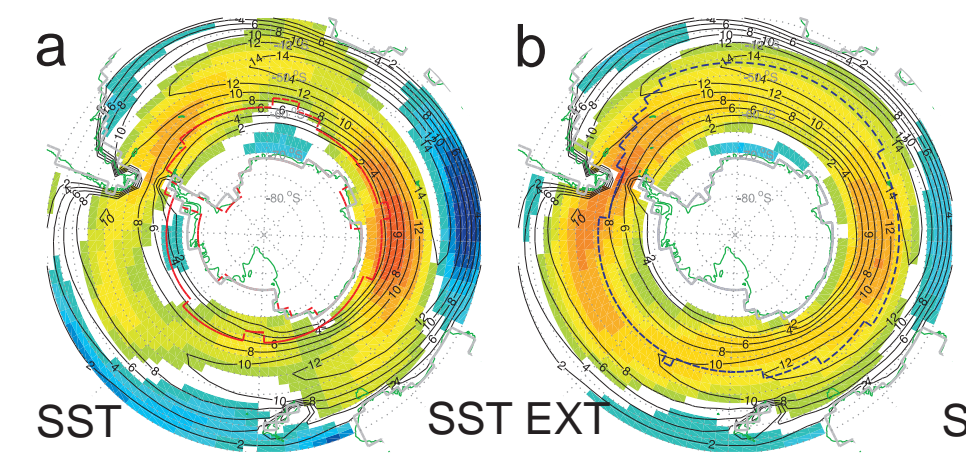

SST EXT
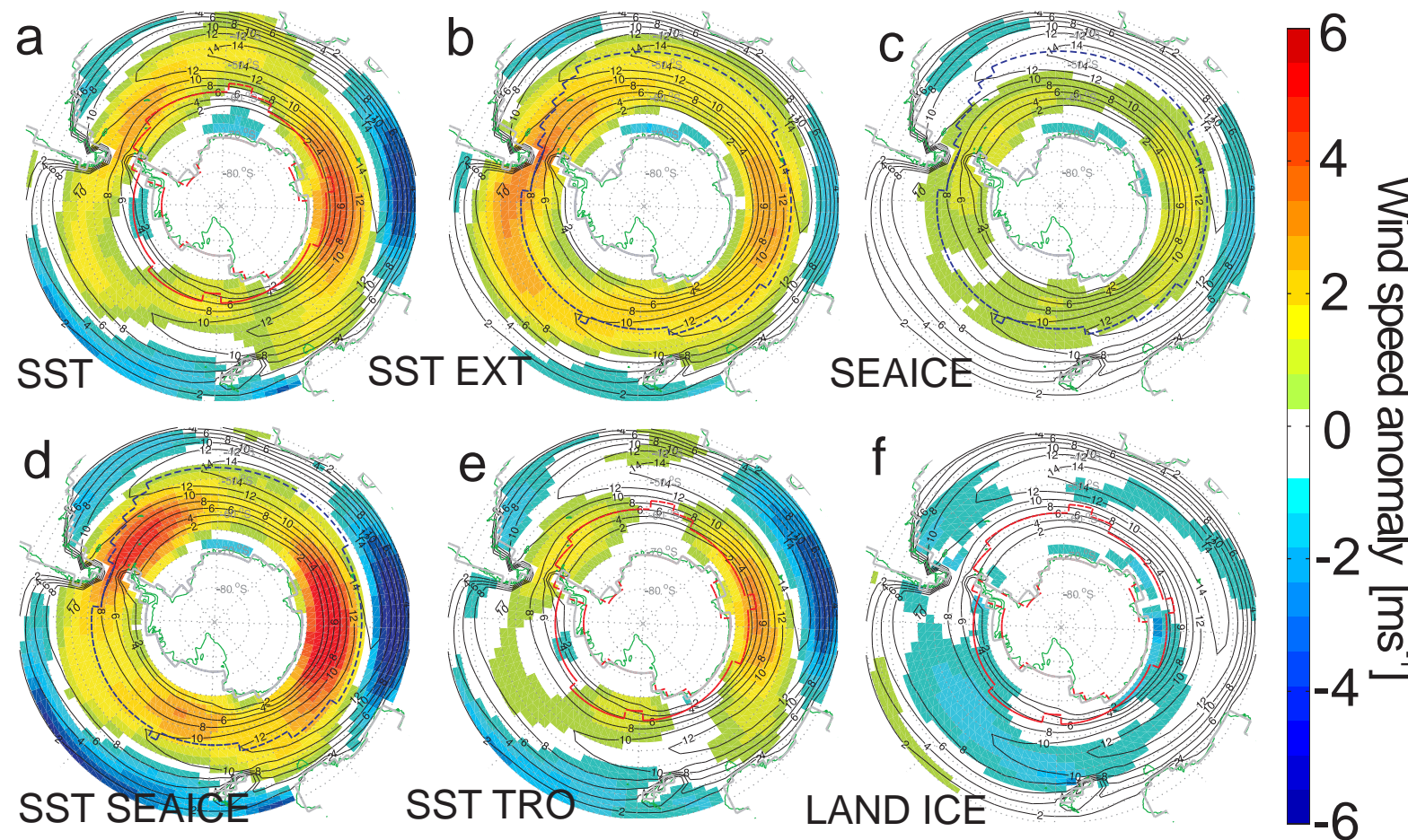

Figure 5: Shading shows the anomalous annual mean $850 \mathrm{hPa}$ westerly wind speed $\left(\mathrm{m} \mathrm{s}^{-1}\right)$. In each case the anomaly shown is glacial simulation minus pre-industrial. The simulations are: (a) sea surface temperature (SST); (b) extra-tropical sea surface conditions (SST EXT); (c) sea-ice (SEAICE); (d) sea surface temperature and sea-ice (SST SEAICE); (e) tropical sea surface temperature (SST TRO); (f) and ice-sheet morphology (LAND ICE). See Table 1 for simulation details. Black contours shows the pre-industrial westerly 850 $\mathrm{hPa}$ wind speed (at $2 \mathrm{~m} \mathrm{~s}^{-1}$ intervals). Red (blue) dashes show the pre-industrial (LGM) $50 \%$ sea-ice edge. 

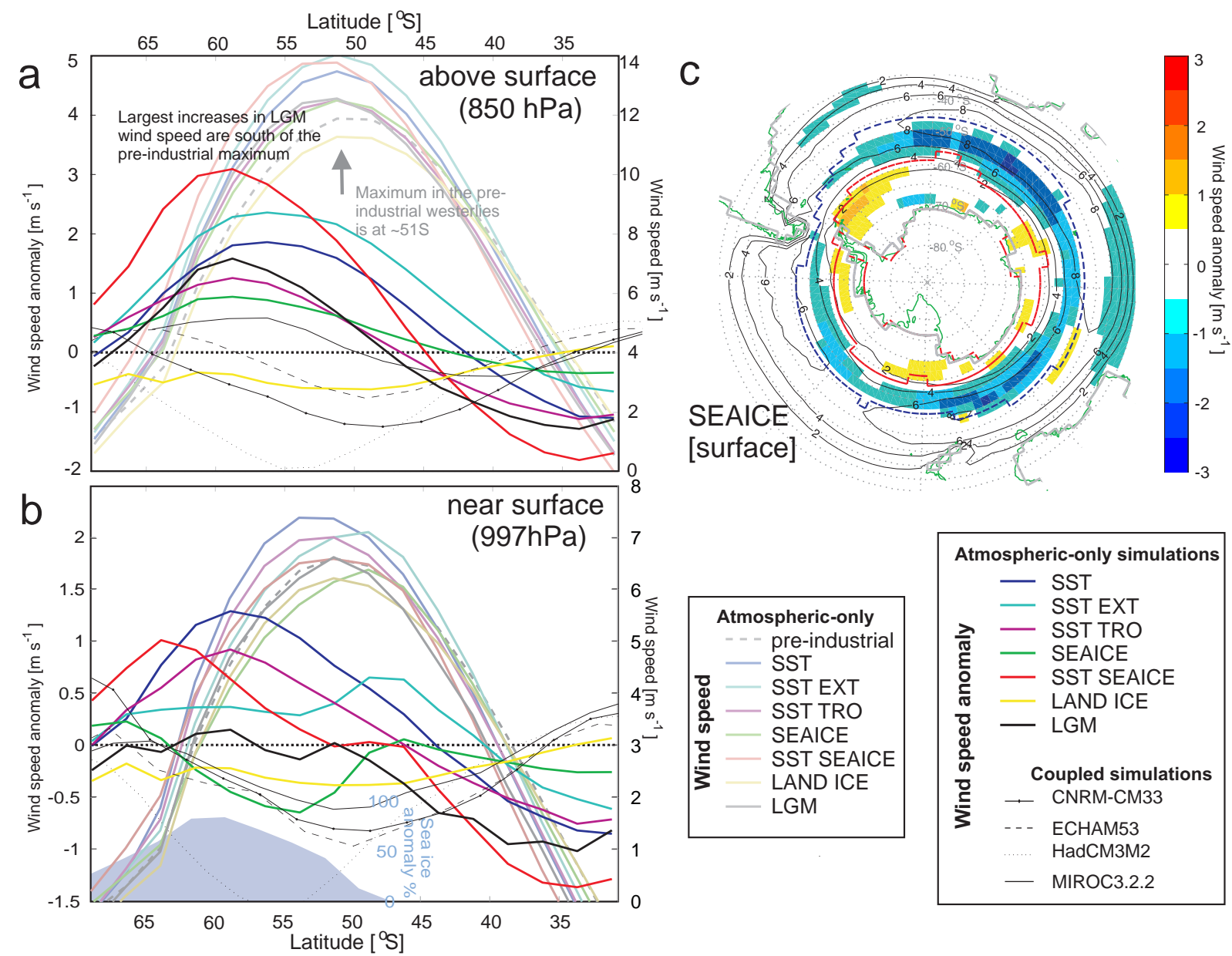

Figure 6: The anomalous annual mean speed $\left(\mathrm{m} \mathrm{s}^{-1}\right)$ on the left axis. For each model this is calculated as glacial simulation minus pre-industrial. Zonal annual mean speed $\left(\mathrm{m} \mathrm{s}^{-1}\right)$ values from each simulation are on right axis. (a) $850 \mathrm{hPa}$, and (b) lowest model level (30 $\mathrm{m}$ ) westerly winds. Anomalous PMIP2 annual mean speed results are shown using thin lines. (c) Shading shows anomalous annual mean surface westerly wind speed (SEAICE minus pre-industrial). Contours shows the pre-industrial surface wind velocity. Red (blue) dashes show the pre-industrial (LGM) 50\% sea-ice edge. 


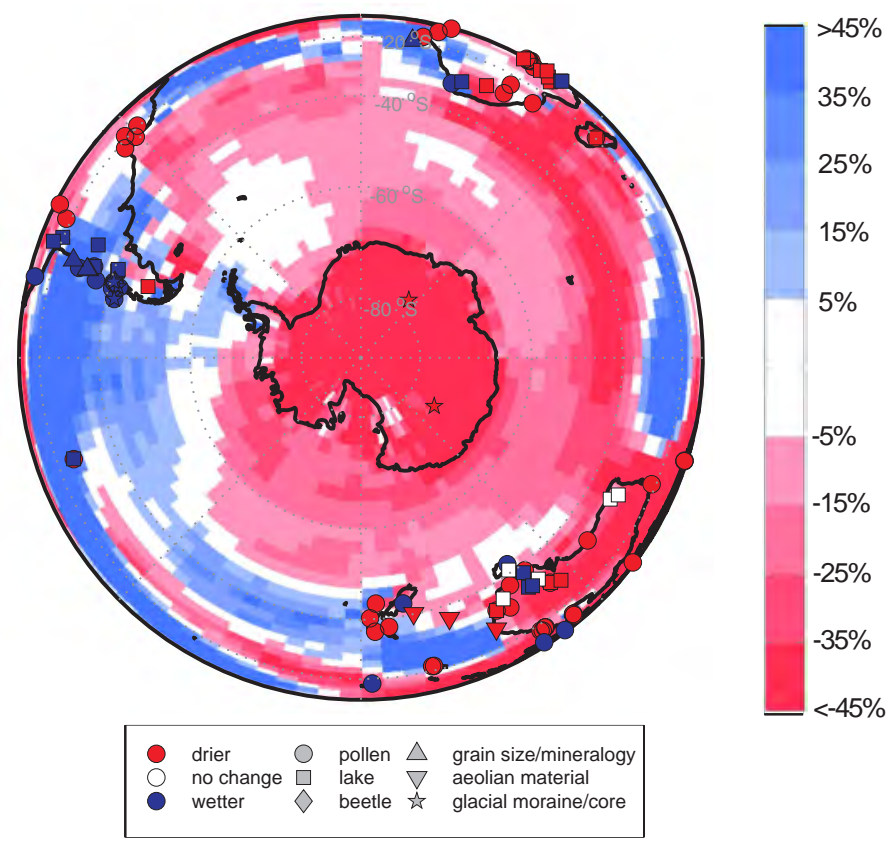

Figure 7: Changes between simulated pre-industrial and glacial precipitation. Kohfeld et al. (submitted) compilation changes in paleo observations of moisture (symbols) and percentage change in precipitation between the LGM and the pre-industrial simulation (LGM minus pre-industrial divided by pre-industrial). 

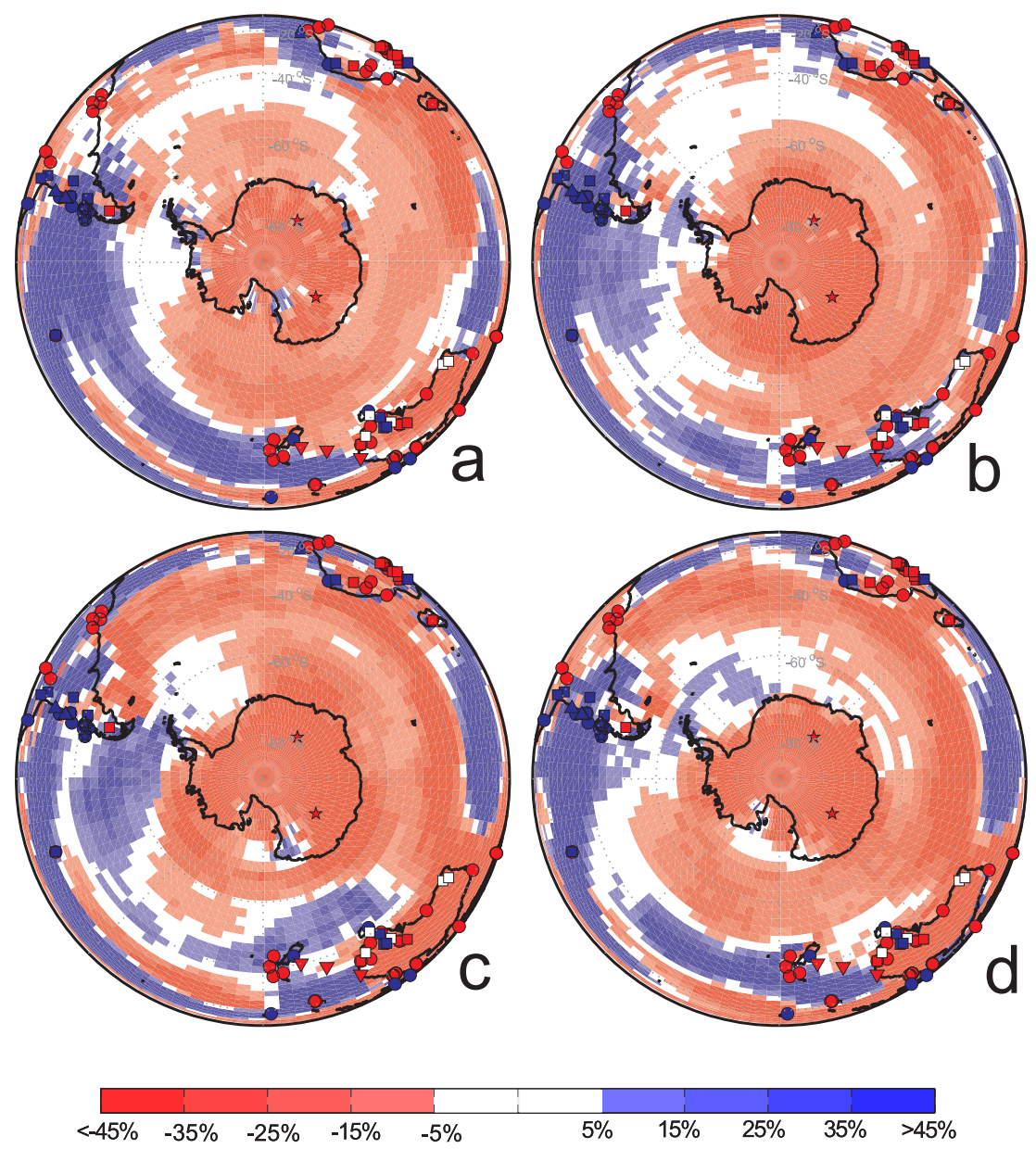

Figure 8: Changes in the moisture fluxes in published studies of paleo-data (symbols) and percentage change in precipitation between the LGM and the pre-industrial simulation, for individual seasons. (a) Austral summer (DJF); (b) austral autumn (MAM); (c) austral winter (JJA); (d) austral spring (SON). 

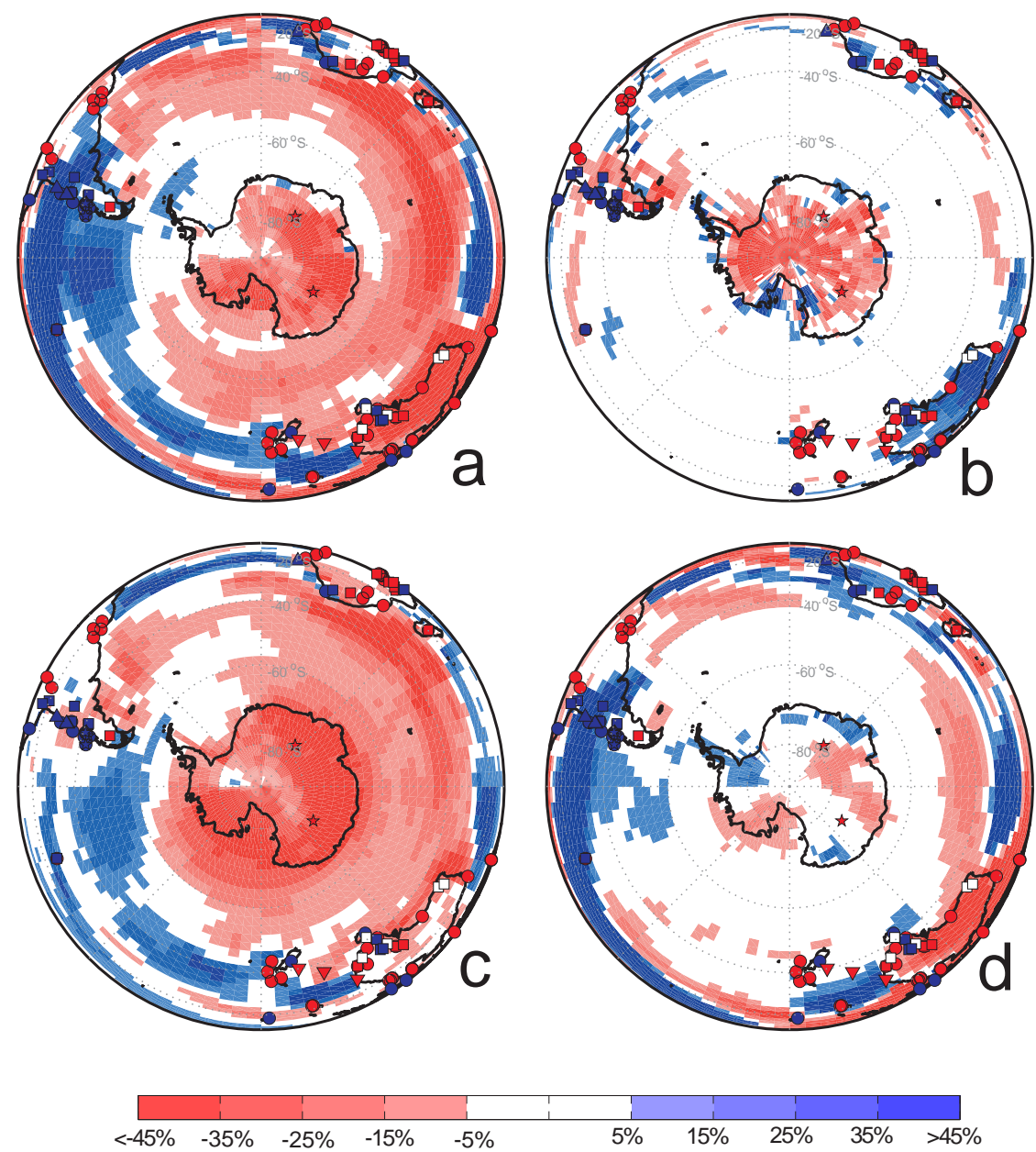

Figure 9: Changes in the moisture fluxes in published studies of compiled paleoobservations (key on Fig. 7) and simulated change in precipitation between the LGM and the pre-industrial simulation (shading). Red is drier, blue is wetter in $10 \%$ shading steps, $\pm 5 \%$ is white. Simulations are (a) SST; (b) LAND ICE; (c) SST TRO; and (d) SST EXT. 

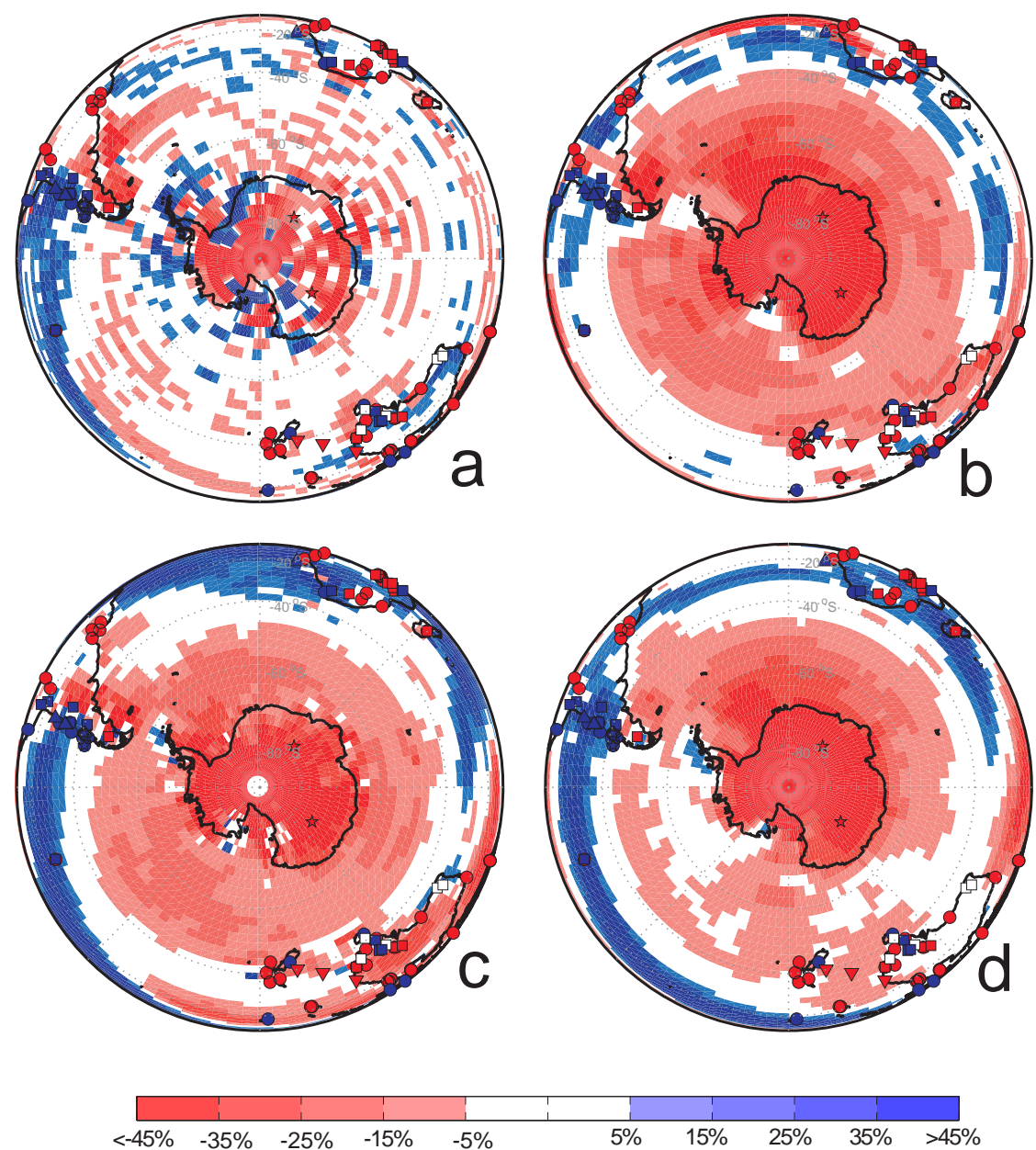

Figure 10: As Fig. 9, but for AOGCM PMIP2.PMIP2 model experiments are (a) CNRMCM33; (b) ECHAM5.3; (c) HadCM3M2; and (d) MIROC3.2.2. 


\section{Appendix A. Additional AGCM sensitivity experiments: Assess- ing the impacts of sea surface condition uncertain- ties}

In addition to the set of core HadAM3 AGCM simulations, and PMIP2 AOGCM multi-model analysis presented (Table 1), additional model simulations were performed to check the sensitivity of modelled wind changes to a wide range of colder sea surface temperatures changes. In each case the sensitivity experiment is identical to the control pre-industrial experiment except with the application of some idealised sst or sea-ice changes (Fig. A.11). The simulations are run for long enough to allow the atmosphere to reach an equilibrium state with the specified boundary conditions. Results are presented as differences between the pre-industrial and LGM simulation for each individual simulation.

The main TRO and EXT experiments (Table 1) are variations of the SST SEAICE simulation. Here we provide an extended sensitivity set based directly on these core simulations. Different fractions of the cold TRO and EXT sst anomaly fields are applied to generate a suite of sensitivity simulations (Fig. A.12 and A.13). The results indicate that wind changes tend to scale with the size of the temperature anomaly applied. This implies that errors in the overall magnitude of the GLAMAP sea surface temperature reconstruction will not affect our main findings.

We also go outside this range and impose very idealised sea surface temperature anomalies. Fig. A.14 shows the results from three such unconstrained simulations. These extra simulations help check the sensitivity of our results to very large GLAMAP sea surface temperature errors. These simulations were obtained by imposing: global; tropical (within $20^{\circ}$ of the equator, and linearly scaled to zero by $30^{\circ}$ ); and zonally uniform, but with a simply linear gradient between the equator and the poles, sea surface temperature anomalies (Fig. A.12). The anomalies applied are zonally uniform in each case. Additionally, a sensitivity simulation is run to check the impact on winds of sea-ice extent, and surrounding sea surface temperature (Fig. 8d). This experiment is like the SEA ICE set-up, however here sea-ice is extended by specifying sea-ice where sea surface temperatures are below $0^{\circ} \mathrm{C}$ (rather than the standard $-1.8^{\circ} \mathrm{C}$ ).

Results indicate that wind changes due to tropical cooling effects are not controlled by the more uncertain details of the cooling pattern. In each case where the tropics are cooled, the Southern Hemisphere westerly winds moves 
a little poleward (strengths decrease on the equatorward side of the band and increase on the poleward side of the band). Thus present LGM sst uncertainties in tropical areas should have a rather limited impact on results. The results from the uniform global cooling simulation show that uniform cooling tends to decrease wind strengths. This agrees with the hypothesis that the overall atmospheric temperature generally controls the overall strength of the atmospheric circulation. Since the small wind strength decreases have little geographical structure, this implies that errors in the overall cooling will also have a limited affect on the simulated wind changes. The idealised gradient change experiment results show more geographical structure in wind changes. This confirms that modelled glacial-interglacial wind changes are sensitive to large errors in meridional temperature gradients (Fig. A.14c). This implies that remaining uncertainties in the position and strength of the glacial Southern Hemisphere westerlies are mainly due to a lack of LGM observations of sea surface conditions over the Southern Ocean. The final sea-ice sensitivity experiment result, showing increases in $850 \mathrm{hPa}$ wind speed in this region where sea-ice is allowed to persist over warmer waters, confirms the conclusion that extended sea-ice coverage drives a small intensification of the westerlies which is largest close to the extended sea-ice region.

\section{Appendix B. An alternative view of mean annual moisture changes} (Fig. 7) 


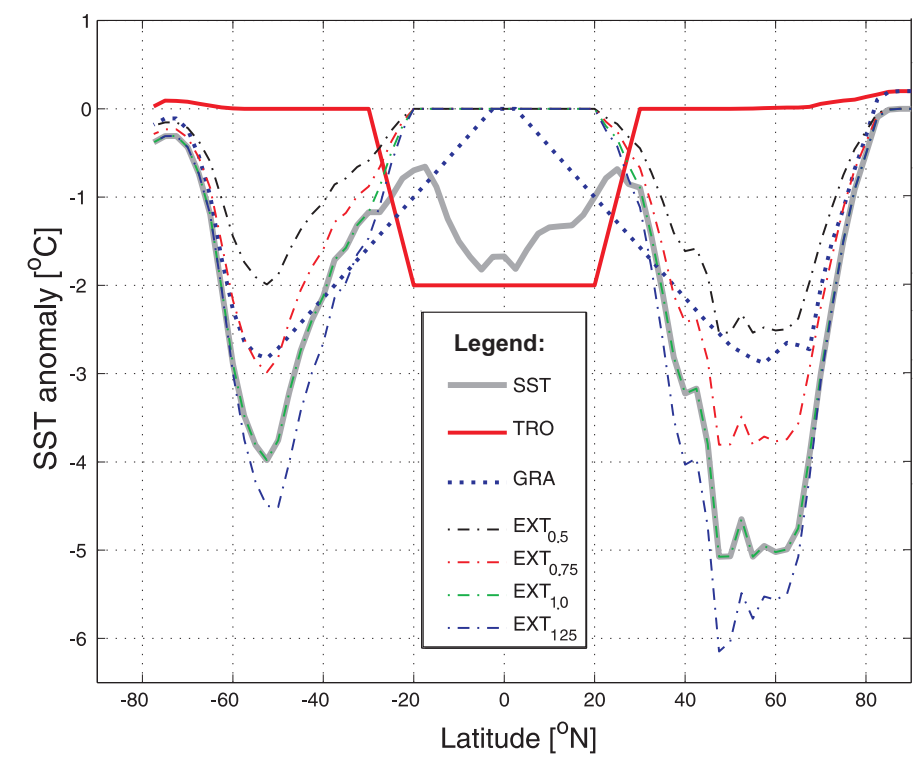

Figure A.11: Mean annual zonal SST anomalies applied to generate SST sensitivity experiments. 

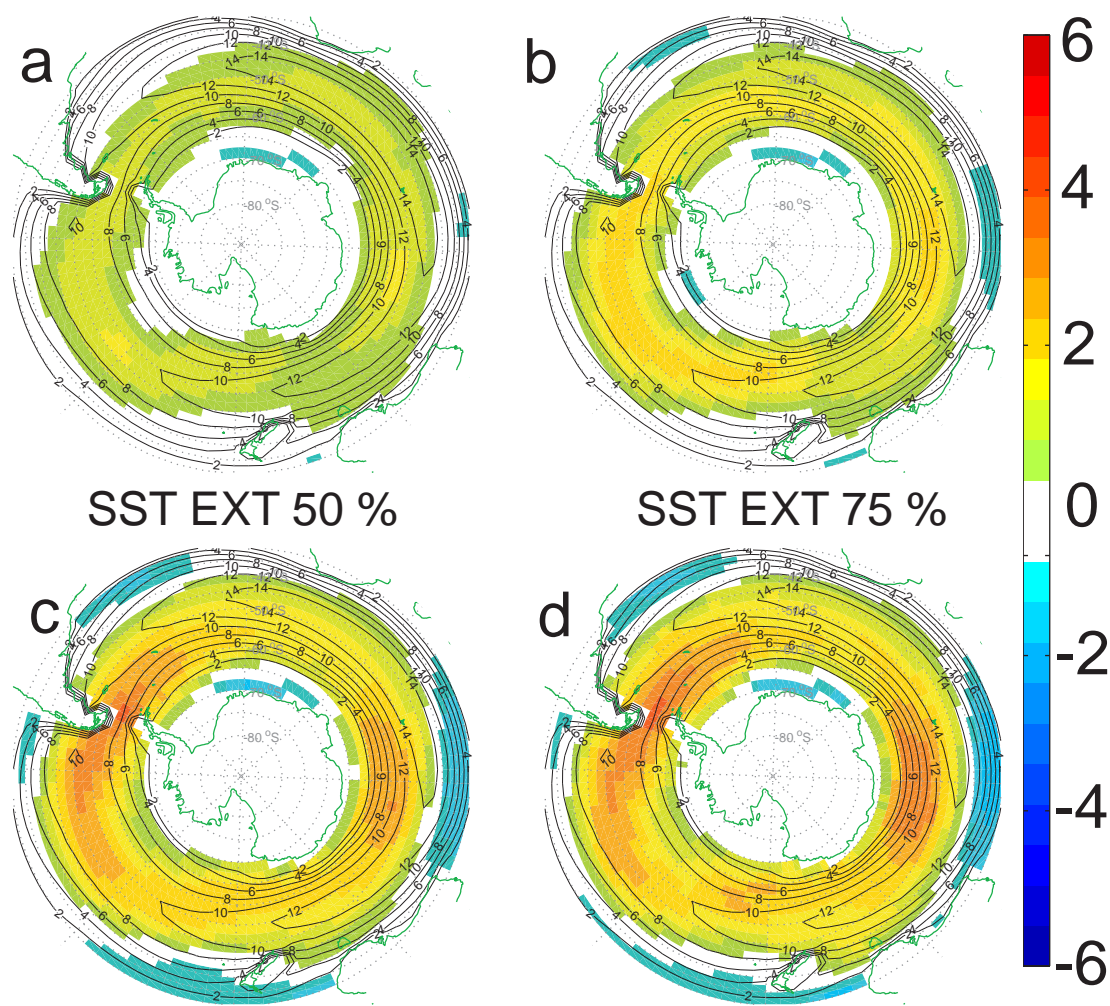

SST EXT $100 \%$

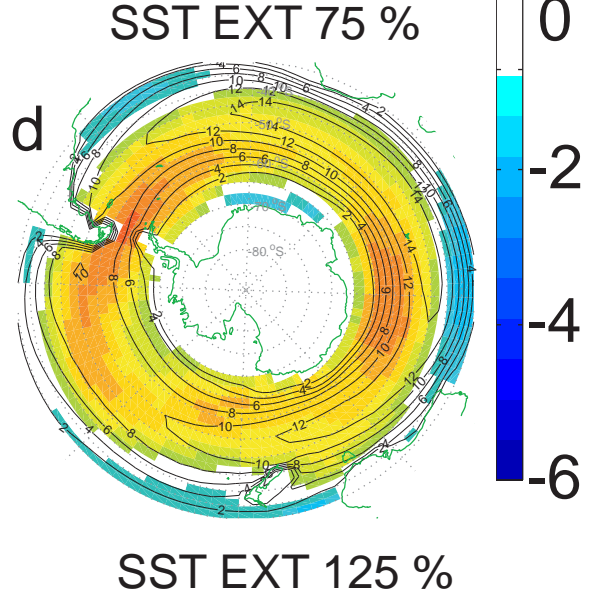

Figure A.12: Differences between $850 \mathrm{HPa}$ pre-industrial and sensitivity study Southern Hemisphere westerlies. Different percentages of the GLAMAP tropical SST anomaly are applied in each experiment (a) 50\%, (b) 75\%, (c) 100\%, and (d) 125\%. (These sensitivity experiments are based on the GLAMAP compilation of observations.) 

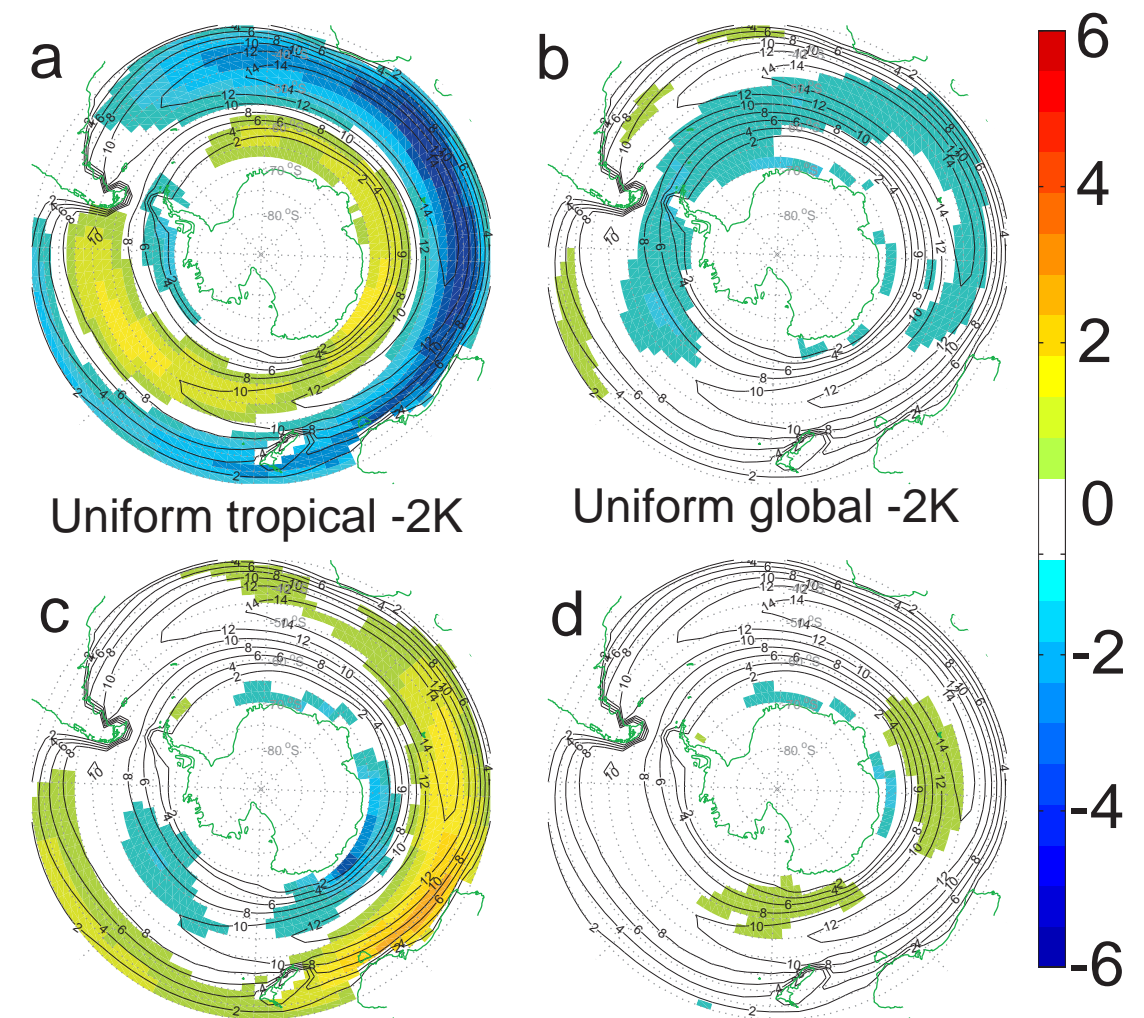

\section{Zonally uniform gradient}

Sea ice edge at $0^{\circ} \mathrm{C}$

Figure A.13: Differences between $850 \mathrm{HPa}$ pre-industrial and sensitivity study Southern Hemisphere westerlies. Different percentages of the GLAMAP extra-tropic SST anomaly are applied in each experiment (a) 50\%, (b) 75\%, (c) 100\%, and (d) 125\%. (These sensitivity experiments are based on the GLAMAP compilation of observations.) 

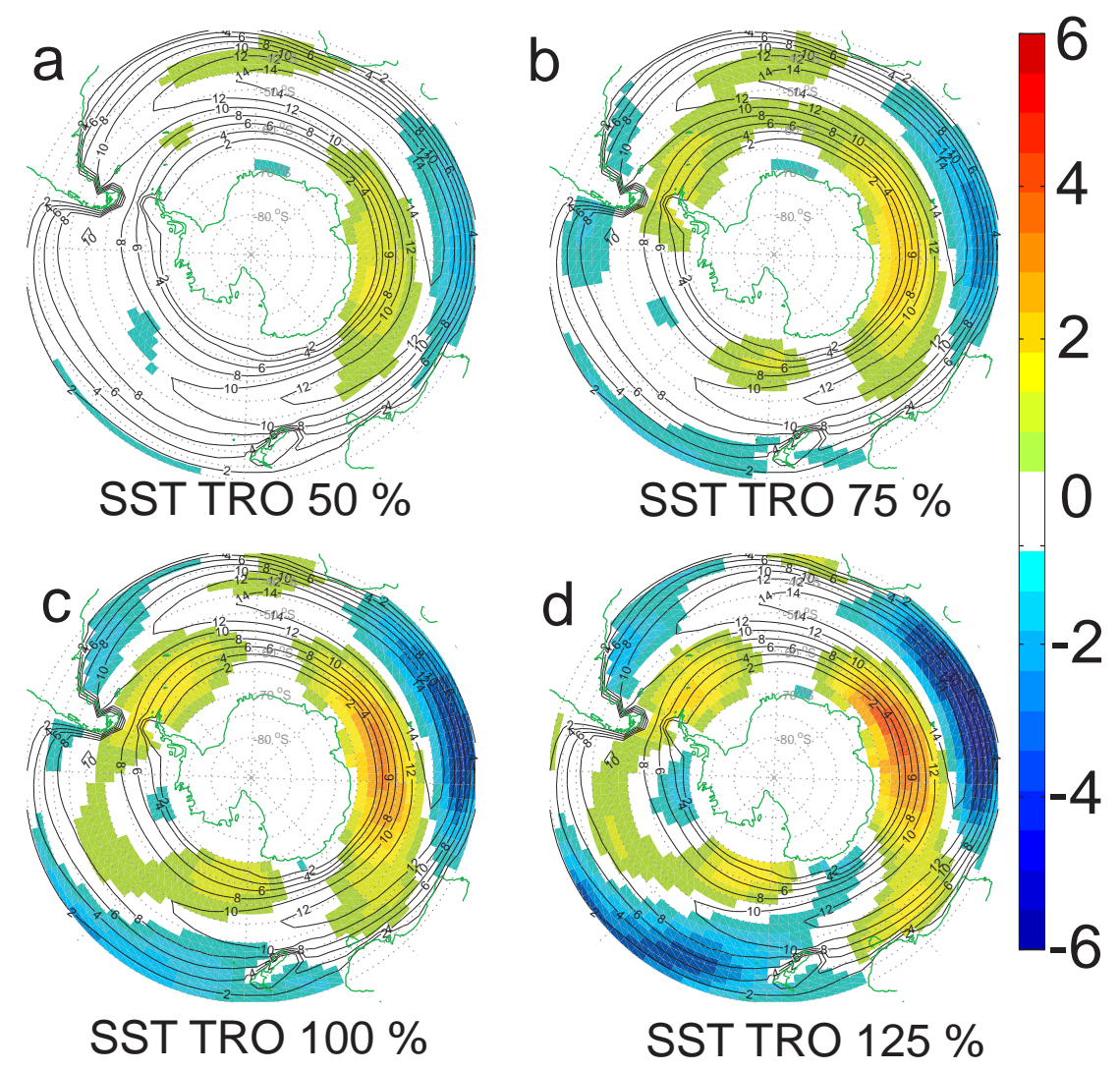

Figure A.14: Differences between $850 \mathrm{HPa}$ pre-industrial and sensitivity study Southern Hemisphere westerlies. Panel (a) a uniform $2 \mathrm{~K}$ tropical cooling; (b) a uniform $2 \mathrm{~K}$ global cooling; (c) a zonally uniform, but meridionally graded, cooling (see Fig. S5); (d) specifying sea-ice for all regions with SSTs less than $\mathrm{O}^{\circ} \mathrm{C}$. (These curiosity driven experiments are not based on observations.) 


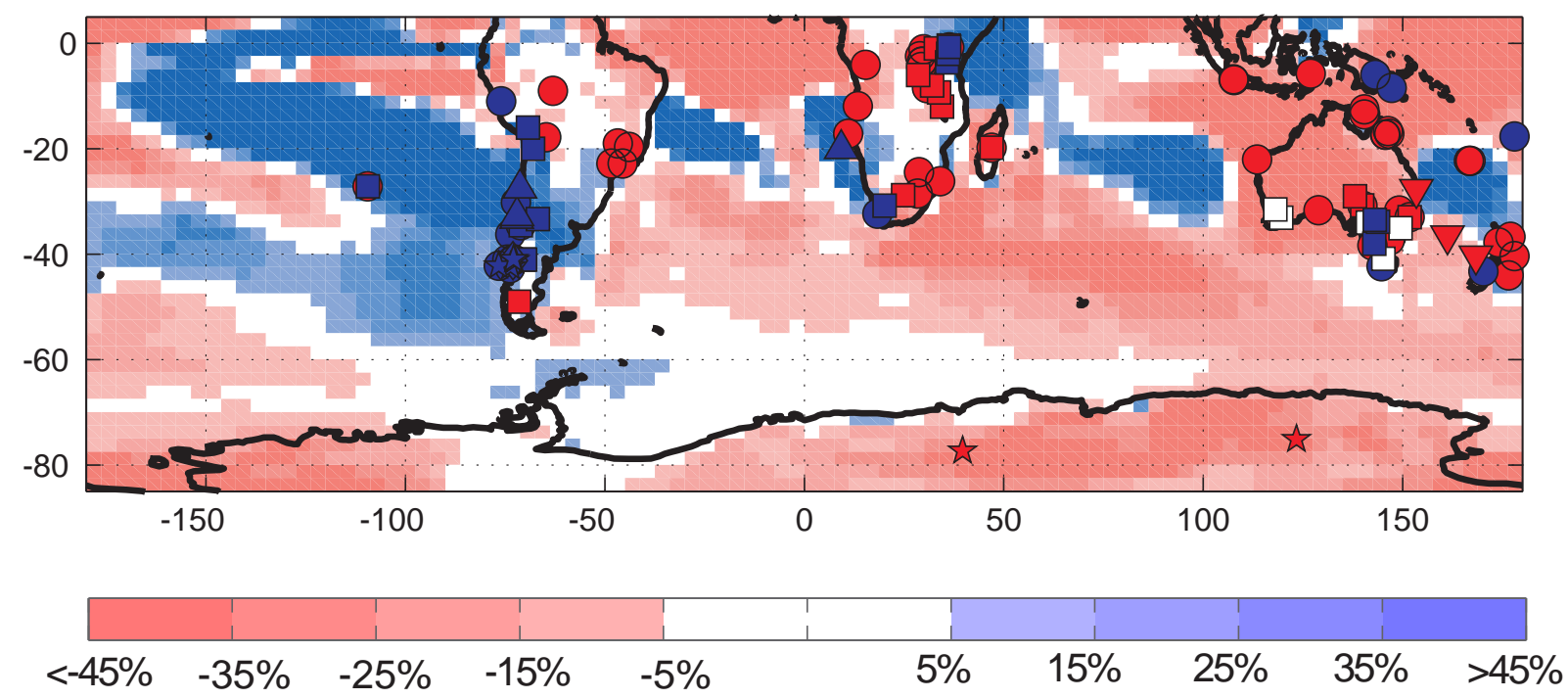

Figure B.15: Changes in the moisture fluxes in published studies of paleo-data (symbols) and percentage change in precipitation between the LGM and the pre-industrial simulation. This is an alternative view of the main Fig. 7 map (using a different projection). 